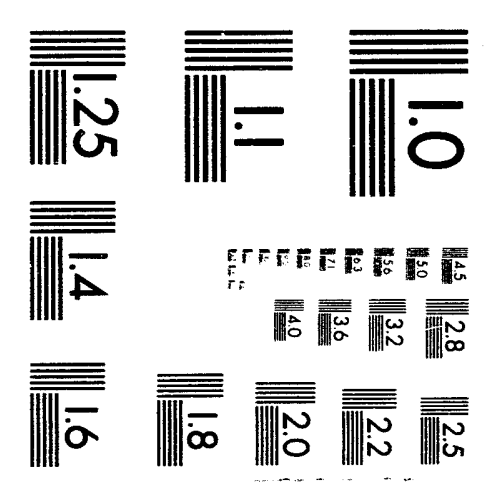



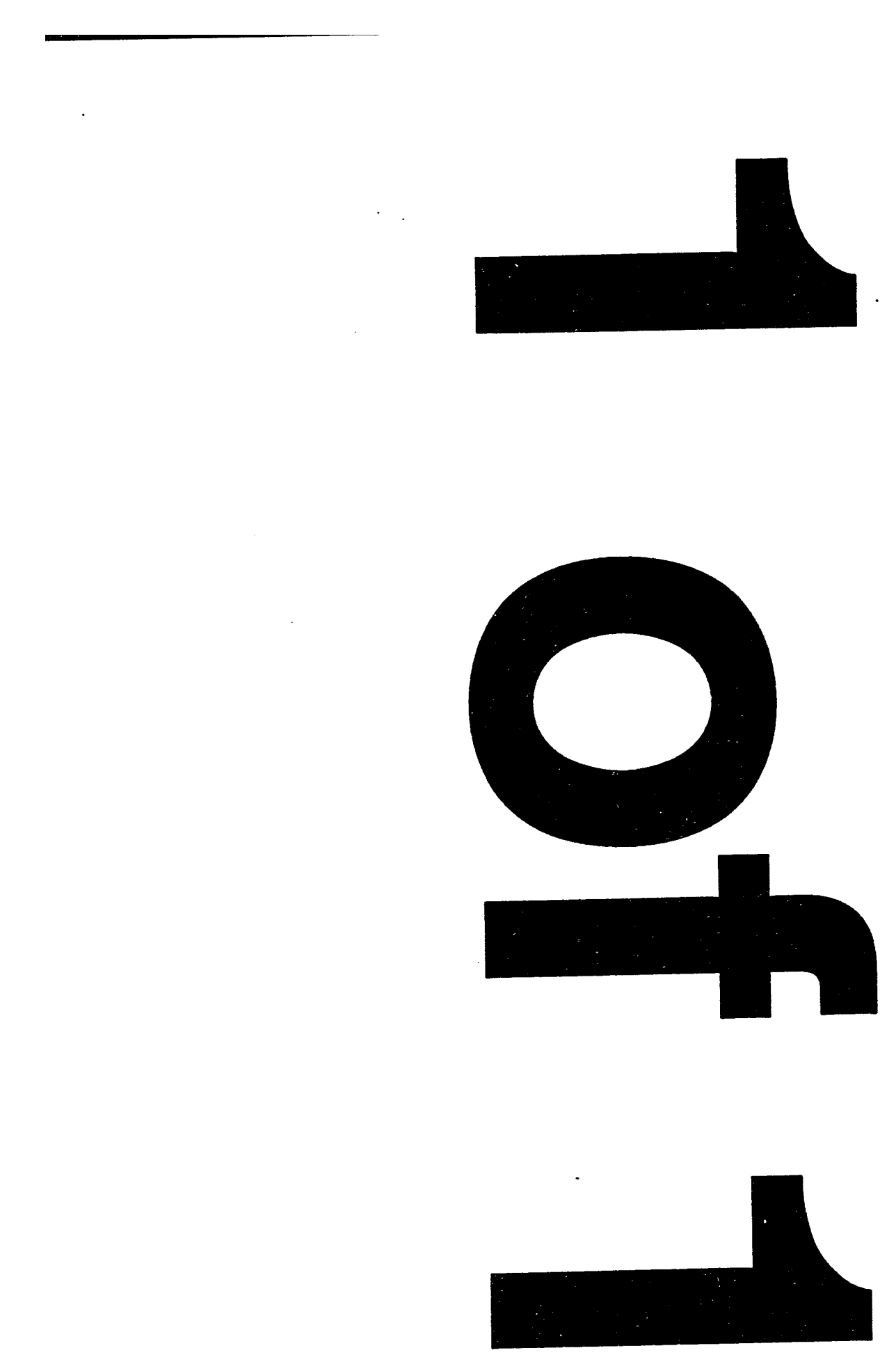


\section{SECOND INTERNATIONAL SYMPOSIUM ON THE BIOGEOCHEMISTRY OF MODEL ESTUARIES: ESTUARINE PROCESSES IN GLOBAL CHANGE}

\section{Jekyll Island, Georgia USA \\ April 14-20, 1991}

\section{Sponsored by:}

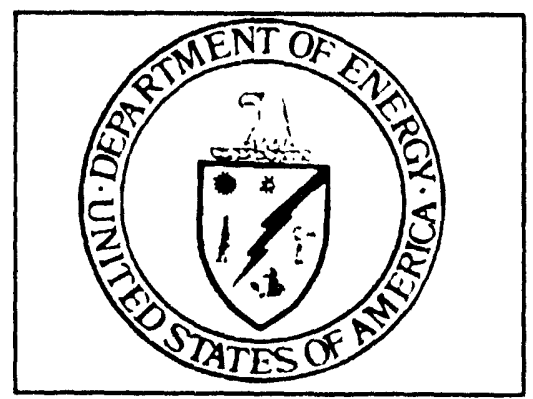

Department of Energy

Skidaway Marine Science Foundation

\begin{tabular}{|c|}
\hline Skidaway Marine \\
Science Foundation
\end{tabular}

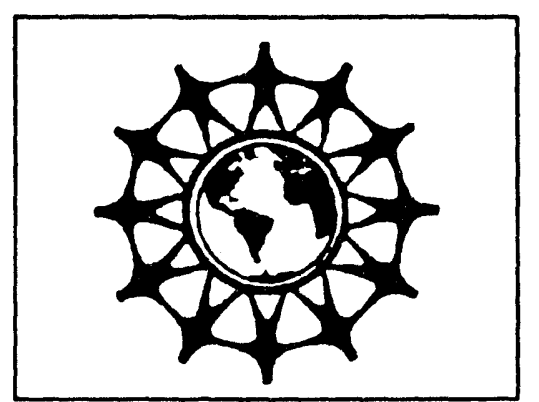

National Science Foundation

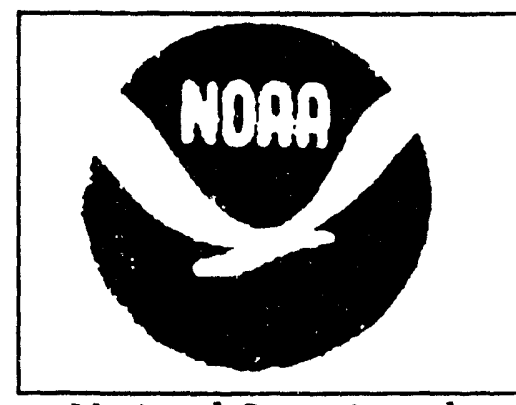

National Oceanic and Atmospheric Administration

Skidaway Institute of Oceanography

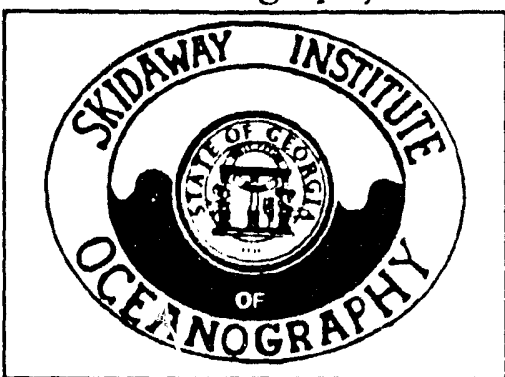

\section{ABSTRACTS}

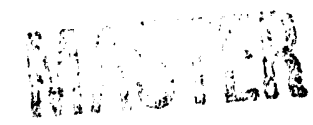




\title{
PREFACE
}

\section{Abstracts in this publication appear}

\section{in alphabetical order by last name of the}

\section{first author listed on the paper to be}

\author{
presented.
}

\section{DISCLAIMER}

This report was prepared as an account of work sponsored by an agency of the United States Government. Neither the United states Government nor any agency thereof, nor any of their employees, makes any warranty, express or implied, or assumes any legal liability or responsibility for the accuracy, completeness, or usefulness of any information, apparatus, product, or process disclosed, or represents that its use would not infringe privately owned rights. Reference herein to any specific commercial product, process, or service by trade name, trademark, manufacturer, or otherwise does not necessarily constitute or imply its endorsement, recommendation, or favoring by the United States Government or any agency thereof. The views and opinions of authors expressed herein do not necessarily state or reflect those of the United States Government or any agency thereof. 
THE ROLE OF Mn IN THE CARBON CYCLE OF ESTUARINE MUDS

\author{
Robert C. Aller \\ Marine Sciences Research Center \\ SUNY at Stony Brook \\ Stony Brook, New York 11794-5000 \\ USA
}

\begin{abstract}
Metal reduction-oxidation cycles are generally assumed to be unimportant in the oxidation of reactive carbon or reduction of oxygen in nearshore sediments. This may not always be the case. In Long Island Sound (LIS), the regular seasonal pattern of variation in planktonic carbon inputs, bioturbation rates, and overlying water oxygen content produce a corresponding dynamic variation in Mn cycling both spatially and temporally. The biogeochemical importance of $\mathrm{Mn}$ is strongly controlled by biogenic particle reworking and irrigation activity, which stimulate internal reduction-oxidation recycling of $\mathrm{Mn}$ in sediments. Estimates of Mn reduction rates and dissolved Mn fluxes in LIS muds indicate that $\mathrm{Mn}$ cycling accounts for little $\mathrm{C}$ oxidation or $\mathrm{O}_{2}$ reduction during winter but can contribute a progressively greater proportion of total metabolism (up to $\mathbf{- 3 0 \%}$ ) as temperature and particle reworking rates increase. The balance between $\mathbf{M n}^{\text {*+ }}$ production and reoxidation within the sediments changes seasonally. Net $\mathrm{MN}^{++}$flux from sediments is often highest of the year following the spring bloom, although total Mn production usually continues to increase during the summer. As either biogenic mixing decreases, $\mathrm{O}_{2}$ in overlying water decreases, or the efficiency of $\mathrm{Mn}$ reoxidation is otherwise lowered, internal $\mathrm{Mn}$ recycling in deposits becomes dramatically less important in carbon oxidation. In regions of LIS that are seasonally hypoxic, the sedimentary Mn-oxide inventory is lost and regained during the course of a year and net $\mathbf{M n}^{*+}$ fluxes are large. The lack of significant bioturbation and reoxidation in these areas, however, greatly lessens the role of $\mathrm{Mn}$ in carbon cycling relative to well-oxygenated regions with active benthic communities.
\end{abstract}




\title{
CHANGEABILITY SCALES OF BIOGEOCHEMICAL BARRIER PARAMETERS IN SOME LARGE ESTUARIES OF PACIFIC WESTERN COAST
}

\author{
V.V. Anikiev, E.P. Varlaty, T.A. Zadonskaya, V.I. Zvalinsky, \\ A.P. Nedashkovsky, and E.N. Shumilin \\ Pacific Institute of Oceanology \\ Far Eastern Division \\ U.S.S.R. Academy of Sciences \\ 7 Radio Street \\ Vladivostok, 690032 \\ U.S.S.R.
}

\begin{abstract}
The biogeochemical barrier at the river-sea system is conditioned by the combination of high gradients of dynamic, physico-chemical, biological parameters of water masses, which may be changed by variations of the river run-off, tidal fluctuations of sea level and other factors.

Special observations were fulfilled for estuarine areas by $R / V s$ "Ac. Lavrentiev," "Pr. Bogorov," and "Ac. Nesemeyanov" in following estuarine areas: the Amur River the Okhotsk Sea and the Sea of Japan, the Razdolnaya River - The Sea of Japan, the Changjiang River - East China Sea, the Mekong River - South China Sea, the Nile River the Mediterranean Sea.
\end{abstract}

A number of factors were studied synchronously: distribution of thermohaline stricture of water masses, current fields, carbonate system, suspended matter, phytozooplanktonic biomass.

The comparison of results of these surveys showed seasonal shifts in biogeochemical barrier locations. Mathematical processing of the data registered at 24-hour stations in various seasons also revealed the short-term changes of characteristics. 


\title{
SOURCES OF SEDIMENT TO THE NEUSE RIVER ESTUARY, NORTH CAROLINA
}

\author{
L.K. Benninger \\ Department of Geology \\ University of North Carolina \\ Chapel Hill, North Carolina 27599 \\ USA
}

\section{$\underline{\text { Abstract }}$}

The Neuse River estuary is part of the large Albemarle-Pamlico estuarine/lagoonal system (APES) of North Carolina. Exchange between the APES and the open ocean is restricted to inlets in the Outer Banks chain of barrier islands, and it is thought that the loss of terrestrially-derived, fine sediment from the APES is minimal.

Freshwater discharge of the Neuse River is low in relation to the size of its estuary; hence the estuary is normally brackish over most of the area which accumulates finegrained sediments. Mud (silt + clay) accumulation rates are low: maximum apparent rates (excess ${ }^{210} \mathrm{~Pb}$, uncorrected for deep mixing) are $\leq 6 \mathrm{~mm} / \mathrm{y}$.

As part of a project to study particle transport, deposition, and accumulation in the Neuse estuary, we have collected radiochemical (and, in some cases, chemical) data on 10 cores. All cores were collected from areas of the estuary where average (pore-water) salinity exceeds 5 per mil, so that composition changes due to salt-induced desorption should have been largely complete. In accord with this expectation 137-Cs sediment inventories $\left(\mathrm{dpm} / \mathrm{cm}^{2}\right)$ are all less than expected from atmospheric deposition and do not vary systematically in the downstream direction. Excess (above background) $\mathrm{Zn}$ decreases downstream, consistent with a local, terrestrial source. Downstream changes in $K$ (increasing), ${ }^{226} \mathrm{Ra} /{ }^{20} \mathrm{Th}$ (decreasing), and fallout $\mathrm{Pu} / \mathrm{Cs}$ inventory ratio (increasing) are all consistent with an admixture of marine-derived sediment in the lower estuary. The immediate source for this sediment is probably Pamlico Sound, but in the longer term there may be input from shelf waters into the APES. 


\section{ELECTROPHORETIC STUDIES OF MODEL COLLOIDAL DISPERSIONS \\ Jasenka Biscan \\ Center for Marine Research \\ Ruder Boskovic Institute \\ Zagreb, Croatia \\ Yugoslavia}

\section{Abstract}

The selected clay minerals and carbonates representing the models of suspended inorganic solid matter in natural aquatic systems were studied. The electrophoretic mobilities of the solid/liquid dispersions were measured and related to the composition of both, the solid phase and the aqueous solution.

The main points of the studies were:

- the electrokinetic charge of individual components under variable ionic strength, $\mathrm{pH}$ and ligand concentration;

- the coexistence of various particles and reflection to the electrokinetic potential;

- the effect of the adsorption of organic molecules (ligands) on the electrokinetic potential;

- any evidence of charge reversal. 


\title{
DYNAMICS OF DISSOLVED AND PARTICULATE PHASES IN ESTUARINE MESOCOSMS
}

Dr. U. Brockmann

Institut fur Biogeochemie und Meereschemie

Universität Hamburg

Martin-Luther-King-Platz 6

D-2000 Hamburg 13

Germany

\begin{abstract}
$\underline{\text { Abstract }}$
The interaction between dissolved and particulate material in estuaries is very difficult to investigate in the estuary itself due to tidal advection as well as transient sedimentation and resuspension of particulate matter. In the turbidity zone of the Elbe River, therefore, mesocosm experiments were performed with $2.3 \mathrm{~m}^{3}$ sized plastic bags, permanently mixed, and a circulation tank of $25 \mathrm{~m}^{3}$ volume allowing simulation of tidal currents. Salinity increase was simulated by successive addition of salt.

During one experiment in the circulation unit - in spite of frequent changes of current speed and coupled variation of turbidity and particulate phosphorus - the concentrations of phosphate remained nearly constant. The independent behaviour of phosphate was confirmed by parallel plastic bag experiments with the same starting conditions, but without sediment and with constant circulation.

In another set of experiments, phosphate concentration in the water was not in equilibrium with the sediment. Therefore, phosphate decreased successively in the circulation tank, coupled with resuspension cycles. This was also the case for nitrate, which was lost to the sediment. At the same time - in the hypertrophicated Elbe water phytoplankton grew, dominated by diatoms. The grazing zooplankton mainly consisted of copepods and foraminifers, reaching significant standing crops within two weeks.
\end{abstract}

(Author unable to be present at Symposium) 


\title{
ACCUMULATION OF ANTHROPOGENIC CONTAMINANTS IN SEDIMENTS OF HALIFAX HARBOUR: 'THE IMPORTANCE OF ESTUARINE CIRCULATION AND SEDIMENT DIAGENESIS
}

\author{
Dale E. Buckley \\ Atlantic Geoscience Centre \\ Bedford Institute of Oceanography \\ Dartmouth, Nova Scotia \\ Canada, B2Y 4A2
}

\begin{abstract}
The metropolitan area around Halifax Harbour has developed over 240 years around a natural deep water fiord-like estuary. With urban and industrial growth over the past 100 years, there has been increasing disposal of waste into the inner harbour. Net estuarine water circulation has contributed to confinement of sewage discharges to the central harbour and to the $\mathbf{7 0} \mathbf{~ m}$ deep inner Bedford Basin. Bottom sediments contain up to $13 \%$ organic carbon because of high loading of organic matter and poor oceanographic flushing. Oxygen uptake in surface sediments is more than $200 \mu \mathrm{g} \mathrm{O}_{2} \cdot \mathrm{g}^{-1} \cdot \mathrm{h}^{-1}$, resulting in steep redox gradients with depth in the sediments and rapid reduction of sulfate. From analyses of ${ }^{210} \mathrm{~Pb}$ dated cores it was found that concentrations of $\mathrm{Pb}, \mathrm{Hg}$, and $\mathrm{Cd}$ were up to 100 times the prehistoric levels, while anthropogenic enrichment of $\mathrm{Cu}$ and $\mathrm{Zn}$ was by a factor of 10. A profile of aliphatic hydrocarbons in a sediment core reflects the exponential increase in sewage contamination over the past 100 years, while polycyclic aromatic hydrocarbons such as benzo(a)pyrene reached an historic peak in the 1950's, reflecting a change in the use of fossil fuels. Most of the $\mathrm{Cu}, \mathrm{Pb}$ and $\mathrm{Zn}$ is bound in the sediments in a labile form, either as an organic complex or in a metastable acid reducible mineraloid. These labile forms account for several hundred tonnes of potentially reactive metal that is found mainly in the upper $50 \mathrm{~cm}$ of bottom muds of the harbour. This anthropogenic reservoir may pose a threat to the future environmental quality of the harbour, even after installation of major sewage treatment facilities.
\end{abstract}




\title{
CARBON INPUTS AND DISTRIBUTION IN ESTUARIES OF TURBID RIVERS: YANG TZE AND YELLOW RIVERS (CHINA)
}

\author{
G. Cauwet \\ Laboratoire de Sédimentologie et Géochimie Marines \\ Université de Perpignan \\ Avenue de Villeneuve \\ 66025 Perpignan Cedex \\ France
}

\begin{abstract}
The excess $\mathrm{Co}_{2}$ emitted by human activities is responsible for an increase of atmosphere temperature due to the green house effect and could have dramatic climatic implications in about 10 years. The role of the Ocean in regulating the carbon cycle is recognized but not perfectly known and particularly the coastal zone could be the most important sink for carbon, and its ability to absorb this carbon excess.

Besides the small depth and the higher productivity, compared to the open ocean, the coastal zone is also collecting most of the river inputs. This carbon flux is negligible, probably less degradable than marine production and concerns only shallow areas.

Chinese rivers are known to be among the most turbid ones in the world, contributing strongly to sediment transport to the oceans. The Yang Tze River (Changjiang), fifth in the world in terms of water discharge $\left(850 \mathrm{~km}^{3} / \mathrm{y}\right)$ is the fourth in terms of solid discharge $\left(490 \times 10^{6} \mathrm{~T} / \mathrm{y}\right)$. The Yellow River (Huang He) is much smaller but with a large watershed and a strong erosion, it is one of the most turbid rivers in the world, sometimes approaching $50 \mathrm{~g} / \mathrm{l}$. These typical characteristics influence strongly the organic carbon content of suspended matter and the concentration of dissolved organic carbon.
\end{abstract}

Particles brought by the Huang He have a low organic carbon content $(0.45$ $0.55 \%)$, while the Yang Tze exhibits values two times higher $(0.9-1.0 \%)$. Deposition in the close vicinity of the river mouth as well as the mixture with marine particles, increases the carbon content $t c$ wards the sea. Seasonal variations can be evidenced from two cruises performed in winter and summer.

Dissolved organic carbon is quite low in both rivers, much lower in the Yang Tze $(1.7-2.2 \mathrm{mg} / \mathrm{l})$ than in the Yellow River $(2-4 \mathrm{mg} / \mathrm{l})$. The contribution of these turbid rivers to the carbon input to the ocean is mainly in the particulate form, thus influencing only the coastal zone. Recycling in the sediment is also probably low, considering the carbon content and the very high sedimentation rate. Nevertheless, for the Yang Tze estuary, it seems that tidal movements are responsible for remobilization of dissolved organic carbon.

These two rivers have a relatively high inorganic carbon content, higher than seawater itself for the Yellow River. Dissolved inorganic carbon (DIC) is generally conservative along the salinity gradient, with the exception of a gap appearing in the low salinity range. While the high concentration in the Huang He can suggest calcite precipitation, it seems less probable in the Yang Tze. 


\title{
NATURAL RADIONUCLIDE STUDIES OF DELAWARE ESTUARINE PROCESSES
}

\author{
Thomas M. Church \\ College of Marine Studies \\ University of Delaware \\ Newark, DE 19716 \\ USA
}

\begin{abstract}
$\underline{\text { Abstract }}$
The natural uranium and thorium decay series provides a series of elements the chemistry and decay times of which reveal key estuarine processes. In turn estuarine processes impose disequilibria on the series which define the rates of many estuarine processes. Radionuclide studies have been conducted in the Delaware estuary and its pervasive salt marshes over the past ten years.
\end{abstract}

The sedimentation chronology of the salt marshes has been established by ${ }^{210} \mathrm{~Pb}$ as nearly that of the rate of sea level rise. Under the present global change, acceleration of sea level rise, this has important implications on estuarine sediment budgets. Sediment and radionuclide gradients in marsh sediment traps point to the important role of storm redistribution. Uranium in the marsh tidal waters reveal extensive uptake in the upper zone of marsh sediments in conjunction with metal/sulfur redox cycles.

In the Delaware estuary, uranium shows conservative behavior except in the upper reaches during the summer season. As in the salt marshes, important uptake processes also occur concurrent with a minimum in alkalinity and maximum in phosphate. This suggests iron/phosphate based scavenging processes which out-compete the carbonatecomplexes which normally stabilize uranium in estuarine and sea waters. Such uptake of uranium in the world's estuaries could constitute a significant global sink for marine uranium.

Radium shows non-conservative excesses in mid-salinities of the Delaware associated with desorption and sediment diffusion sources. The isotopic ratios of the thorium series radium daughters (relative to the uranium series daughter $\mathbf{R a - 2 2 6}$ ) reveal important sediment sources of ${ }^{228} \mathrm{Ra}$ as augmented by the scavenging of the ${ }^{228} \mathrm{Th}$ intermediate parent in the case of ${ }^{22} \mathrm{Ra}$. Seasonal cycles of radium which parallel productivity suggest important interaction of estuarine radium with the cycles of siliceous diatoms.

Thorium and lead in the Delaware estuary show dominant particle association. During periods of high productivity, the ${ }^{210} \mathrm{~Pb}$ grand-daughter, ${ }^{210} \mathrm{Po}$, shows seasonal dissolved excesses in the water, particularly in tidal waters of salt marshes. The polonium excesses persist out onto shelf areas as the lead parent is removed by particulate sedimentation processes. The polonium excesses are believed associated with the organic complexation of polonium which could include alkylation. 


\title{
CARBONYL SULFIDE IN THE ESTUARINE ENVIRONMENT AND ITS RELATIONSHIP TO THE GLOBAL OCS CYCLE
}

\author{
Gregory A. Cutter and Joel Radford-Knoery \\ Department of Oceanography \\ Old Dominion University \\ Norfolk, Virginia 23529-0276 \\ USA
}

\begin{abstract}
$\underline{\text { Abstract }}$
Carbonyl sulfide (OCS) has the longest atmospheric residence time (2-7 years) of all the sulfur gases. This allows OCS to be the primary source of sulfate aerosols in the stratosphere, and thus function as a radiatively important gas. Fluxes from the marine environment and fossil fuel combustion are amongst the largest contributors of carbonyl sulfide to the atmosphere. In the open ocean OCS concentrations range from 10-200 $\mathrm{pmol} / \mathrm{L}$, but near the coast concentrations rise dramatically. In surface waters of the Chesapeake Bay and Pettaquamscutt Estuary (Rhode Island) we have found OCS concentrations ranging from $1000-5000 \mathrm{pmol} / \mathrm{L}$; in anoxic bottom waters of these estuaries up to $30 \mathrm{nmol} / \mathrm{L}$ have been detected. Concentrations of OCS in the porewaters of Chesapeake Bay sediments reach micromolar levels, indicating that sediments may be an important source of OCS to the water column.
\end{abstract}

Our estuarine results have two important ramifications to the global OCS cycle. First, fluxes from the coastal environment are significantly larger than those from the open ocean. The estuarine sea-air flux of OCS is estimated to be up to $1100 \mathrm{nmol} / \mathrm{m}^{2}$ day, over ten times greater than open ocean values. In this manner fluxes from coastal waters may account for over $60 \%$ of the OCS emissions from the marine environment. The second aspect concerns production mechanisms for OCS. The photolysis of dissolved organic sulfur compounds has been suggested as the mechanism by which OCS is produced in the open ocean. However, our estuarine results suggest that organic matter regeneration in sediments may also be an important source of OCS. Overall, the biogeochemical cycle of OCS in estuaries appears to have a quantitatively important role in the global cycle of this sulfur gas, and therefore to the global climate. 


\title{
NUTRIENT PROCESSING AND THE DEVELOPMENT OF TIDAL CREEK ECOSYSTEMS
}

\author{
R.F. Dame and L.R. Gardner \\ Baruch Institute \\ University of South Carolina \\ Conway, South Carolina 29526 \\ USA
}

\begin{abstract}
$\underline{\text { Abstract }}$
The North Inlet estuarine system encompasses the spectrum of interaction between the ocean and the uplands typical of the southeastern United States. The system is an ebb-dominated, barbuilt estuary with good flow connection to the sea and some freshwater input.

The North Inlet basin has evolved from a forested, relic beach ridge terrain under a regime of slowly rising sea level $(2 \mathrm{~mm} / \mathrm{yr})$. This mode of development is supported by historic tide gauge data, ${ }^{210} \mathrm{~Pb}$ dating of sediment cores, the presence of spodic soil horizons and tree roots at shallow depths beneath the marsh surface, and the presence of relic "cat eye" ponds at the edge of the salt marsh. As sea level rises, the boundary between forest and salt marsh receded upslope ar: forest spodosols are gradually transformed into marsh soils by salinization, the deposition and mixing of marine mud into the upper horizons of the forest soil and the accumulation of reduced sulfur via sulfate reduction. As the forest is transformed into a salt marsh basin, hydraulic gecmetry of the black water (fresh) stream increases to handle the increasing volumes of ticial discharge. Forest sands move seaward while marine muds are transported into the basin.
\end{abstract}

As water moves between the forest and the sea, it passes through creeks in different developmental stages. Large mature creeks interact with the ocean while young ephemeral creeks drain the uplands and intertidal marsh zones. Intermediate stage creeks connect these two and are characterized by the presence of oyster reefs. Net nutrient fluxes appear to be different in each developmental stage.

The "Bly Creek" study addressed the flux of materials between a creek at the intermediate stage of development and the adjacent mature system. Material fluxes from a freshwater stream draining into Bly Creek from the adjacent uplands was also observed. The role of the salt marsh and the oyster reefs in determining material fluxes was examined. Bly Creek imports particulate materials and exports dissolved forms.

The "Outwelling" study at North Inlet focused on the flux of materials between the mature creeks and the Atlantic Ocean. All constituents were exported seasonally and annually from the estuary - except total sediments, imported during fall and winter, and chlorophyll $a$ imported in the summer and fall. The export of carbon, nitrogen and phosphorus was high compared to the estuarine systems.

On a unit area primary productivity is higher and nutrient fluxes are lower in Bly Creek (intermediate stage of development) as compared to the mature North Inlet system. These observations support the general ecosystem development hypothesis that nutrient storage and retention is higher in younger systems than more mature systems where growth is lower and fewer nutrients are needed. 
PLANT PIGMENTS AS TRACES OF ESTUARINE PROCESSES

Rodger Dawson

Chesapeake Biological Laboratory

University of Maryland

P.0. Box 38

Solomons, MD 20688

USA

(Abstract not submitted in time for publication) 


\title{
COMPOSITION AND FATE OF PARTICULATE ORGANIC MATTER IN A SHALLOW ESTUARY SUBMITTED TO EUTROPHICATION
}

\author{
R. Fichez', P. Dennis ${ }^{2}$ and T.D. Jickells ${ }^{2}$ \\ 'Centre d'Océanologie de Marseille \\ Station Marine d'Endoume \\ Rue de la Batterie des Lions \\ 13007 Marseille, France \\ ${ }^{2}$ University of East Anglia \\ School of Environmental Sciences \\ NR4 7TJ Norwich, England
}

\begin{abstract}
$\underline{\text { Abstract }}$
This work was part of the British Joint Nutrient Study (JONUS) programme developed to determine the fate and consequences of anthropogenic nutrient inputs to the North Sea. As nutrients and particulate organic material are linked by heterotrophic degradation and autotrophic production, part of the study had to focus on the particle pool. The particulate organic matter (POM) composition was studied in an eutrophic estuary (The Wash, Great Ouse, England) from March 1990 to January 1991. Organic carbon (OC), organic nitrogen (ON), chlorophyll $a(\mathrm{Cha})$, pheopigment $(\mathrm{Ph})$, carbohydrate (CH), protein (PR) and lipid (LI) content of particles was analysed. This biochemical study was associated with the analysis of the stable isotopic composition of organic carbon expressed as $\delta^{13} \mathrm{C}$ ratio.

Previous results demonstrated the estuarine ecosystem to be highly influence by the suspended load and subsequent turbidity. Suspended particulate matter (SPM) $<100 \mathrm{mg} \mathrm{l}^{-1}$ made autotrophic development possible when SPM $>100 \mathrm{mg} \mathrm{l}^{-1}$ inhibited algal growth. Related changes in biochemical composition were observed. Carbohydrate content was very high during phytoplankton blooms accounting for more than $45 \%$ of the total organic carbon in May. The organic carbon associated with complex organic matter (calculated as the difference between particulate $\mathrm{OC}$ and the sum of carbon associated with simple organic compounds: $\mathrm{CH}, \mathrm{PR}, \mathrm{LI}$ ) was high in the river and gained increasing importance during the high suspended load period (August to January).

The $\delta^{13} \mathrm{C}$ proved to be a good tracer of the origin and fate of the organic matter as values decreased from $-30 \%$ in the river to $-19 \%$ at sea. The use of $\delta^{13} \mathrm{C}$ as a tracer was very accurate when studying and comparing transects. However, on the basis of the whole survey, no clear linear relationship could be drawn between salinity and $\delta^{13} \mathrm{C}$ data. It proved the system to be more complex than a simple two end member system as often assumed for estuarines. Resuspension processes certainly have a great impact on the SPM composition due to the shallowness of the Great Ouse estuary. Other factors such as variations in water temperature or effluent flows (sewage) may also contribute to the variation in the $\delta^{13} \mathrm{C}$ values of particulate organic matter.
\end{abstract}

(Author unable to be present at Symposium) 


\title{
SILVER IN SAN FRANCISCO BAY: AN URBAN ESTUARY
}

\author{
A.R. Flegal and G.J. Smith \\ Institute of Marine Sciences \\ University of California, Santa Cruz \\ Santa Cruz, CA 95069 \\ USA
}

\begin{abstract}
$\underline{\text { Abstract }}$
There is a pronounced spatial gradient in dissolved $(<0.4 \mu \mathrm{m})$ silver concentrations in the San Francisco Bay estuary. Concentrations in the northern reach are relatively low ( $25 \mathrm{pmol} / \mathrm{kg}$ ) and conservatively distributed along a salinity gradient. Conversely, concentrations in the southern reach are relative high $(\leq 250 \mathrm{pmol} / \mathrm{kg})$ and nonconservatively distributed. These spatial gradients are similar to those of some other trace elements $(\mathrm{Cu}, \mathrm{Co}, \mathrm{Ni}$ and $\mathrm{Zn})$ and nutrients $\left(\mathrm{PO}_{4}, \mathrm{NO}_{2}+\mathrm{NO}_{3}\right)$ in the estuary. They are associated with differences in hydrologic residence times and internal cycles within the system. The magnitude of internal fluxes of natural and anthropogenic sources of silver are estimated by mass balance calculations and comparisons with other trace element and nutrient fluxes. Differences between the cycling of silver and other trace elements within the estuary are consistent with theoretical differences in their speciation and complexation.
\end{abstract}




\title{
LOW REACTIVITY OF TRACE ELEMENTS IN STRATIFIED \\ ESTUARIES: EXAMPLE OF THE RHONE RIVER DELTA (FRANCE)
}

\author{
D.M. Guan, F. Elbaz-Poulichet and J.-M. Martin \\ Institut de Biogéochimic Marine (Unité associée au CNRS n³86) \\ Ecole Normale Supérieure \\ 1 rue Maurice Arnoux \\ F-92120 Montrouge \\ France
}

\begin{abstract}
The fate of trace elements during estuarine mixing has long been studied but often concluded to conflicting results. It is becoming more and more obvious that beyond the physicochemical characteristics of trace elements, the complex dynamic and sedimentological processes control their behaviour in the estuarine environment. In this study, we describe the results observed in one typical stratified system: the Rhône river delta.

The Rhône River is the major source of fresh water, dissolved salts, nutrients and sediments to the Gulf of Lions and exerts a major effect upon the primary production of the North Western Mediterranean Sea. It presents a well-defined salt wedge and spreads over the sea surface forming a typical plume due to the negligible tidal amplitude in the Gulf of Lions. Finally, its drainage basin is highly industrialized.

The dissolved trace elements $(\mathrm{Cd}, \mathrm{Cu}, \mathrm{Ni}, \mathrm{Pb}$ and $\mathrm{As}$ ) have been determined during a four-year period (1987 - 1990) in framework of the EROS-2000 project. The dissolved concentrations in river water are $30.9 \pm 8.5 \mathrm{nM}$ for As; $0.29 \pm 0.15 \mathrm{nM}$ for Cd; $38.3 \pm 8.1 \mathrm{nM}$ for $\mathrm{Cu} ; 28.6 \pm 7.5 \mathrm{nM}$ for $\mathrm{Ni}$ and $0.40 \pm 0.11 \mathrm{nM}$ for the $\mathrm{Pb}$, respectively, indicating a discharge. In general, the river end-member concentration of dissolved trace elements decreases with the increasing of river discharge.

In the plum of the Rhône, dissolved trace elements exhibit a conservative behaviour during the mixing of river water and mid-shelf water. Similarly, the proportions of particulate trace elements and aluminum are almost constant in the estuarine zone. This low reactivity results from the relatively short resident time of river water and particles in the plume of the Rhone. Then, the Rhône river input of dissolved trace elements to the Mediterranean Sea can be simply computed from the monitoring from the river endmember concentrations.
\end{abstract}




\title{
THE RECORD OF ORGANIC MATTER PRODUCED IN ESTUARIES: CASE STUDY OF THE KRKA ESTUARY AND THE STEROLS
}

\author{
J. Laureillard, J. Fillaux, and A. Saliot \\ Laboratoire de Physique et Chimie Marines \\ de l'Université Pierre et Marie Curie \\ UA CNRS 353; Tour 24 \\ 4 Place Jussieu \\ 75252 Paris Cedex 05 \\ France
}

Abstract

Changes in our environment and their consequences on biogeochemical cycles often play a direct role in ecosystems that could be followed by changes in biological populations density or diversity and in consumption or production of mineral and organic species. Thus, it could be possible to study these changes by analyzing the record of chemical species involved in representative ecosystems. Among various candidates, organic tracers are potentially powerful molecules because of the specificity of their biosynthesis for different organisms, the adaptation of biosynthetic systems to environmental parameters, and their stability in recent environments (Lajat et al., 1990).

In order to assess the use of these molecules in estuarine systems for recording river and marine organic matter sinks, we have chosen the Krka estuary, which is characterized by a marked stratification of waters, with closely associated fresh and marine planktonic populations and the presence of a halocline, which accumulates both living and dead material sinking from fresh waters (Zutic and Legovic, 1987).

The fingerprints of sterols associated with particulate matter and present in the dissolved phase were determined in samples collected in the Krka estuary in May 1988. Analyses were performed by gas chromatography and gas chromatography/mass spectrometry. Large differences were observed between sterol fingerprints obtained for river waters and marine waters.

River waters were characterized by the predominance of stigmasterol, followed by brassicasterol, sitosterol and cholesterol in the particulate matter. Higher sterol concentrations and different fingerprints were observed in the dissolved phase, which reflects both excretion and lysis of dead organisms. If stigmasterol predominated, cholesterol and 24-methylenecholesterol indicated inputs from other planktonic organisms.

Marine waters showed much lower concentrations and very different characteristics: large predominance of cholesterol in both particulate and dissolved phases, enrichment of the dissolved phase in marked planktonic imprints through 27 Nor, 24-methylcholesta 5,22,dien-3B-ol. The halocline exhibited variable enrichments with each phase and compound, underlining sensitivity of the sterol signatures with regard to changes in productivity/consumptions of autochthonous fresh and marine planktonic organisms. 


\title{
STABLE OXYGEN ISOTOPE DISTRIBUTION AND DISSOLVED \\ SILICA IN THE LENA DELTA AND \\ LAPTEV SEA (USSR)
}

R. Letolle', J.-M. Martin', A.J. Thomas', V.V. Gordeev", S. Gusarova and I. Sidorov ${ }^{3}$

\author{
'Laboratoire de Biogéochimie Isotopique, Université de Paris VI, \\ France \\ ${ }^{2}$ Institut de Biogéochimie Marine, ENS, Montrouge, France \\ ${ }^{3}$ P.P. Shirshov - Institute of Oceanology, USSR Academy \\ of Sciences \\ 4Arctic and Antarctic Institute - Leningrad, USSR

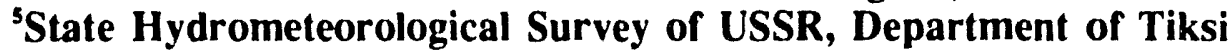

\section{Abstract}

Water samples from Lena River estuary and Laptev Sea have been analyzed to determine their stable oxygen isotope composition $\left({ }^{18} \mathrm{O} /{ }^{16} \mathrm{O}\right)$. The measurement at the Lena River reference station gives a $\delta^{18} \mathrm{O}=-18.8 \%$ in both surface and bottom waters. In the surface plume waters a nearly perfect correlation is found between chlorinity and $\delta^{18} \mathrm{O}$

$$
\delta^{18} \mathrm{O}=18.9+0.787 \mathrm{Cl}-(\mathrm{n}=15 ; \mathrm{r}=0.999) \text {. }
$$

A few values lie below this correlation; they all correspond to surface samples collected in the Buorkaya Gulf and most likely reveal the occurrence of "old water" masses. $\delta^{18} \mathrm{O}$ values in deep waters also fall below the surface plume correlation line.

Dissolved silica concentrations exhibit a large scattering. However, when they are related to the hydrological structure which has been identified with $\delta^{18} O$ data a more coherent picture is shown. Concentrations in the surface plume decrease more or less regularly from $3.4 \mathrm{mg} / \mathrm{l}$ in the Lena River to $0.5 \mathrm{mg} / \mathrm{l}$ at the "saline" end member (Cl$=14 \mathrm{~g} / \mathrm{l})$.

Results from the Buorkaya Gulf are quite distinct with a clear deficiency in the surface water and an excess in the deep waters.

These $\delta^{18} \mathrm{O}$ and dissolved silica variations are discussed in relation with the hydrology and the biological production of the investigated area. 
SEASONAL IRON CYCLING IN THE MARINE ENVIRONMENT:

THE IMPORTANCE OF LIGAND COMPLEXES WITH FE (II) AND FE (III)

IN THE DISSOLUTION OF FE (III) MINERALS AND PYRITE, RESPECTIVELY

George W. Luther, III

College of Marine Studies

University of Delaware

Lewes, Delaware 19958

USA

\begin{abstract}
A biogeochemical cycle is presented for the reactivity of iron in salt marsh sediments. The main reactions of the iron cycle are (1) solubilization of Fe (III) by organic ligands, (2) reduction of soluble Fe (III) to Fe (II) by these ligands, soluble reduced sulfur or solid phase reduced sulfur, (3) the oxidation of the resulting $\mathrm{Fe}$ (II) (complexed to organic chelates) by Fe (III) minerals, and (4) the formation of iron sulfide minerals when dissolved sulfide is in excess. The cycle of iron solubilization will continue as long as bacteria and/or plants produce organic ligands. The cycle will stop when sulfate reduction rates are high and organic ligand production is low. At this point soluble hydrogen sulfide reacts with Fe (II) and Fe (III) to form sulfide minerals. The reactions which represent the iron cycle indicate that the iron mineral system has substantial acid/base buffering capacity.

The ligands responsible for the cycling of iron are weak field anionic ligands containing oxygen as the ligating atom. The electron transfer from $\mathrm{Fe}$ (II) complexes to Fe (III) minerals is discussed using the molecular orbital approach. An outer sphere electron transfer is possible.

Laboratory evidence is presented for the reaction of $\mathrm{Fe}$ (III) complexes with pyrite over the $\mathrm{pH}$ range of 4 to 6.5. The $\mathrm{Fe}$ (II) production rate and $\mathrm{pH}$ decrease are consistent with field data from Great Marsh, Delaware. The direct oxidant for the oxidation of pyrite and other reduced sulfur compounds in salt marsh sediments is $\mathrm{Fe}$ (III) rather than oxygen based on the cycle and data presented. Oxygen is not present in any porewaters sampled in this work. This is consistent with the microelectrode work of other researchers. Manganese oxides are not likely oxidants in salt marsh sediments in Great Marsh, Delaware because they are not as abundant as iron (III) minerals.
\end{abstract}

The iron cycle presented should occur in other marine or freshwater sedimentary systems and in aquatic systems with oxic/anoxic interfaces. 


\title{
FLOW CYTOMETRY DETECTION OF FLUORESCENT PARTICLE ANALOGUES
}

\author{
J.K. Marsh,, ${ }^{1,2}$ A.J. Bale,' and K.R. Dyer ${ }^{2}$ \\ 'Plymouth Marine Laboratory \\ West Hoe \\ Plymouth PLJ 3DH \\ United Kingdom \\ ${ }^{2}$ Institute of Marine Studies \\ Polytechnic Southwest \\ Plymouth PL4 8AA \\ United Kingdom
}

\begin{abstract}
$\underline{\text { Abstract }}$
A tracing technique combining the use of highly fluorescent particle analogues with automated detection by flow cytometry for studies of cohesive particle behaviour in natural water systems is described. Flow cytometry is a rapid, automated analytical system capable of resolving the composition of a particle population on a particle-byparticle basis in terms of light scattering (size) and fluorescence characteristics using laser optic technology. This capability allows the quantification of tracers at much greater dilution than is feasible by optical microscopy. The automated nature lends itself to the analyses of large numbers of samples generated by environmental studies.

Particle tracing using fluorescent particles has been employed previously for studies of bioturbation and beach dynamics. The novel combination of cytometry with the use of highly fluorescent, inert, formaldehyde-resin particles (size distribution of $0.1-20 \mu \mathrm{m}$,

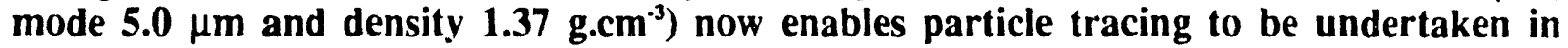
cohesive sediment systems on a large scale and in dynamic areas, e.g., estuaries. This paper describes the analytical methodology which has been developed and its application to dispersion measurements in a clay settling lagoon. The potential for a range of environmental applications is discussed.
\end{abstract}




\title{
FIRST ASSESSMENT (OF TRACE METALS DISTRIBUTION \\ IN A PRISTINE AQUATIC ENVIRONMENT: \\ THE LENA RIVER ESTUARY (USSR)
}

\author{
J.-M. Martin,' D.M. Guan,' F. Elbaz-Poulichet,' \\ A.J. Thomas,' and V.V. Gordeev ${ }^{2}$ \\ 'Institut de Biogéochimie Marine \\ Ecole Normale Supérieure \\ 1 rue Maurice Arnoux \\ 92120 Montrouge \\ France \\ ${ }^{2}$ Institute of Oceanology \\ U.S.S.R Academy of Sciences \\ Moscow \\ U.S.S.R.
}

Abstract

Dissolved and particulate trace metals have been determined in the Lena river estuary during September 1989. The river water end-member concentrations of dissolved $\mathrm{Cd}, \mathrm{Cu}, \mathrm{Ni}, \mathrm{Pb}, \mathrm{Zn}$ and $\mathrm{Fe}$ are respectively 0.03-0.07 $\mathrm{nM}, 9.4 \mathrm{nM}, 5.1 \mathrm{nM}, 0.08 \mathrm{nM}$, $5.4 \mathrm{nM}$ and $412 \mathrm{nM}$. These concentrations are of the same order of magnitude as those observed in unpolluted rivers of the world. Dissolved $\mathrm{Cd}$ and $\mathrm{Pb}$ behave almost conservatively during estuarine mixing. The behaviour of $\mathrm{Fe}$ results in net removal during estuarine transport. There is an apparent addition of dissolved $\mathrm{Cu}$ in the $5 \%$ $10 \%$ chlorinity range, which is caused probably by the remobilisation from estuarine particles. Particulate $\mathrm{Ni}, \mathrm{Pb}$ and $\mathrm{Zn}$ do not show any significant reactivity during estuarine mixing. In contrast, the concentration of particulate $\mathrm{Cu}$ increases from the Lena river to the Laptev Sea. 


\title{
RESPONSES OF ARSENIC METHYLATION PROCESSES TO TEMPERATURE CHANGES IN ESTUARIES
}

\author{
G.E. Millward, L. Ebdon and A.P. Walton \\ Institute of Marine Studies \\ Polytechnic South West \\ Plymouth PL4 8AA \\ United Kingdom
}

\begin{abstract}
$\underline{\text { Abstract }}$
A series of carefully controlled laboratory experiments have been carried out to investigate the effect of temperature on the release of methylated arsenic from porewaters, macroalgae and phytoplankton. These experiments were used to examine the effects of changes in water temperature associated with global warming.

Sediment samples from the freshwater and seawater end members of the Tamar Estuary, UK, were incubated under natural conditions at $5^{\circ} \mathrm{C}$ and $15^{\circ} \mathrm{C}$. The appearance of dissolved arsenic species in the overlying waters was monitored as a function of time using a directly-coupled GC-AAS analytical technique. The freshwater sediments released dimethylarsenic (DMA) in preference to monomethylarsenic (MMA) with the concentrations of both species reaching a steady state in the overlying water after $250 \mathrm{~h}$. Considerably more DMA was produced at $15^{\circ} \mathrm{C}$ than at $5^{\circ} \mathrm{C}$ and the amount of MMA produced appeared to be insensitive to a temperature increase. In contrast, the seawater sediments always produced more MMA than DMA and the increase in temperature had little effect on the production of MMA but stimulated the liberation of additional DMA. The release of dissolved arsenic species by the macro-algae Ascophyllum nodosum was examined under estuarine conditions at $5^{\circ} \mathrm{C}$ and $15^{\circ} \mathrm{C}$. At the higher temperature the release rates were $0.4 \mu \mathrm{g} \mathrm{As} / \mathrm{kg} / \mathrm{h}$ for MMA and $3.2 \mu \mathrm{g} \mathrm{As} / \mathrm{kg} / \mathrm{h}$ for DMA, whereas at $5^{\circ} \mathrm{C}$ the rates were $0.2 \mu \mathrm{g} \mathrm{As} / \mathrm{kg} / \mathrm{h}$ and $0.5 \mu \mathrm{g} \mathrm{As} / \mathrm{kg} / \mathrm{h}$, respectively. Again, the appearance of MMA seems to be insensitive to temperature change. Further experiments were also carried out on the population of the diatom Skeletonema costatum, which released DMA at a rate of about $200 \mu \mathrm{g} \mathrm{As} / \mathrm{kg} / \mathrm{h}$.

The results of the laboratory experiments are compared to field measurements in the Tamar Estuary spanning a temperature range of $10^{\circ} \mathrm{C}$. An estuarine cycle for methylated arsenic is proposed and the implications of climate-induced changes of water temperature on the fate of arsenic in mid-latitude estuaries is discussed.
\end{abstract}

(Author unable to be present at Symposium) 


\title{
CHEMICAL AND BIOLOGICAL CHARACTERIZATION OF PARTICLES BY FLOW CYTOMETRY IN THE KRKA ESTUARY, YUGOSLAVIA
}

\author{
P. Moreira-Turcq, J.-M. Martin and A. Fleury \\ Institut de Biogeochimie Marine \\ Unité de Recherche Associée au CNRS nº386 \\ Ecole Normale Superieure \\ 1, rue Maurice Arnoux \\ 92120 Montrouge \\ France
}

\begin{abstract}
$\underline{\text { Abstract }}$
Flow cytometry has been used to characterize suspended particles in the Krka estuary (Yugoslavia). This technique allows the rapid characterization and quantification of particles based on simultaneous multiple measurements of particle light scatter and natural or induced fluorescence.

The determination of organic particles was carried out by staining with fluorescein isothyocianate (FITC). The autofluorescence of photosynthetic pigments (chlorophyll-a and phycoerytrin) present in phytoplankton population was measured. Cellular DNA (algae and bacteria) was evidenced using DAPI (4;,6-diamino-2 phenylindole). The carbohydrates (galactose and glucose) were stained by lectins conjugated to FITC and used to determine organic coatings and detritus.
\end{abstract}

These preliminary results show that the Krka is a relatively homogeneous estuary, where $c a 80 \%$ of suspended particles is organic, most of these particles being living cells. The Guduca River, a small tributary discharging to the upper estuary, is the only location where a significant proportion of mineral particles are observed.

The presence of organic coatings (carbohydrates) on mineral particles has been obtained from the difference between the total number of "organic-like particles" and living cells and detritus. 


\title{
ESTUARINE PLUME ZONES: SOURCES OR SINKS FOR ESTUARINE CHEMICAL DISCHARGES?
}

\author{
Alan W. Morris, Robin J. M. Howland and Rose Wood \\ Plymouth Marine Laboratory \\ Prospect Place, The Hoe \\ Plymouth PL1 3DH \\ United Kingdom
}

\begin{abstract}
$\underline{\text { Abstract }}$
The results from three cruises surveying nutrient distributions in the coastal discharge of the Humber Estuary, UK, are used to examine ways of quantifying the influence of estuarine plume zones on the transfer of land-derived material from estuaries to coastal seas.

The data are examined in three ways. Firstly, the utility of the mixing curve procedure, conventionally applied in estuarine research, has been examined. This method is only partially useful, in winter for nitrate and silicate, when biological controls are negligible, but is complicated by subsidiary inputs and non-steady-state conditions. The method is inapplicable to phosphate in this system due to phosphate inputs to the outer Humber Estuary.

Secondly, mass-balancing of nutrients, based on estimates of the rates of nutrient controlling processes within the plume, is attempted. This method is complicated by temporal and spatial process heterogeneity within the plume zone, particularly with respect to primary production, in non-winter conditions, and to transfers across the sediment/water interface.

Thirdly, estimates of fluxes emanating from the estuary mouth are compared with estimates across the plume boundary based on computer modelling of residual (nontidal) water transport within the plume. It is argued that, without unlimited resources, this procedure is probably the only practical way to obtain quantitative information at present.
\end{abstract}




\title{
PATHWAYS OF TRACE ELEMENTS IN THE ZAIRE RIVER AND ESTUARY
}

\author{
Rob. F. Nolting and Anuschka Otten \\ Netherlands Institute For Sea Research \\ P.O. Box 59
}

1790 AB, Den Burg, Texel

The Netherlands

\begin{abstract}
Because of the existence of a submarine canyon which starts $30 \mathrm{~km}$ upstream, fresh water discharge by the Zaire River flows, as a thin jet stream, without mixing over the stagnant deeper oceanic waters. The extreme stratification is responsible for the development of low $(0.05 \mathrm{ml} / \mathrm{l})$ oxygen conditions in the saline underlying watermass.

During a survey with the Dutch R.V. Tyro in November, December 1989, sediment cores, suspended matter- and water samples were collected in the Zaire River, estuarycanyon and adjacent ocean. The sediments from the cores were sliced and treated with $0.1 \mathrm{~N} \mathrm{HCl}$, to determine the easy leachable metal fraction, and the residue was total destructed. Preliminary results indicate that: The leachable fractions of metals were rather uniform with depth in the sediment cores at individual stations as well as in the estuary as a whole. In contrast, at a station in the Atlantic Ocean (4000 $\mathrm{m}$ depth some 200 miles offshore), behaviour of metals changed however considerably. For example:

\section{Estuary:}

$\begin{array}{llr}\mathrm{Cu} & 30 \mu \mathrm{g} / \mathrm{g} & 20 \\ \mathrm{Cr} & 90 \mu \mathrm{g} / \mathrm{g} & 7 \\ \mathrm{Ni} & 30 \mu \mathrm{g} / \mathrm{g} & 20 \\ \mathrm{Cd} & 0.5 \mu \mathrm{g} / \mathrm{g} & 70 \\ \mathrm{Fe} & 4.5 \% & 35\end{array}$

\section{Atlantic Ocean:}

\section{\% Leachable}

$\begin{array}{ll}\mathrm{Cu} & 120 \mu \mathrm{g} / \mathrm{g} \\ \mathrm{Cr} & 120 \mu \mathrm{g} / \mathrm{g} \\ \mathrm{Ni} & 120 \mu \mathrm{g} / \mathrm{g} \\ \mathrm{Cd} & 1.5 \mu \mathrm{g} / \mathrm{g} \\ \mathrm{Fe} & 4.5 \%\end{array}$

\% Leachable

65

40

40

20

12
\end{abstract}

The dissolved metal concentrations in the riverwater were, $\mathrm{Cu} 30 \mathrm{nM}, \mathrm{Cd} 150 \mathrm{pM}$, $\mathrm{Zn} 400 \mathrm{nM}$, Fe $10 \mu \mathrm{M}$ and $\mathrm{Mn} 190 \mathrm{nM}$, but despite the freshwater character of the surface layer in the estuary these concentrations decreased in seaward direction. Dissolved metal concentrations reased however dramatically over the thermo-halocline. As an example, the dissolved $F e$ concentration at mid-estuarine stations drops from $\sim 14$ $\mu \mathrm{M}$ (mostly in colloidal form) in the freshwater surface layer to $0.8 \mu \mathrm{M}$ in the deep saline water within $8 \mathrm{~m}$. On the other hand dissolved Fe in porewaters increased again till very high concentrations of $400 \mu \mathrm{M}$, suggesting release from the anoxic sediments. In contrast, this concentration is only $5 \mu \mathrm{M}$ at the deep Atlantic station.

It is suggested that most of the sediment, with adsorbed metals, supplied by the river is caught in the estuary-canyon, and only a small part of the very fine fraction can escape to the open ocean. This sedimentation creates anoxic conditions which result due to mineralisation and redox processes in very high dissolved $\mathrm{Fe}$ and $\mathrm{Mn}$ concentrations in porewaters.

The distribution of metals in bottom-water, pore-water and sediment will be discussed in relation to the extreme redox-boundaries that exists in the study area. 


\title{
BIOGEOCHEMISTRY OF NUTRIENTS AND TRACE METALS IN HOOD CANAL, WASHINGTON
}

\author{
Anthony J. Paulson, Herbert C. Curl, Jr. and Richard A. Feely \\ NOAA \\ Pacific Marine Environmental Laboratory \\ 7600 Sand Point Way, N.E. \\ Seattle, Washington 98115-0070 \\ USA
}

\begin{abstract}
Hood Canal was chosen as a model estuarine system to explore the role that biological production and subsequent recycling processes play in controlling trace metal distributions. Hood Canal is a fjord-like estuary with a shallow embayment at the landward end of the fjord (Lynch Cove). In the summer of 1986, nutrients were depleted in the surface in the landward-most reach. In deeper waters, phosphate concentrations were inversely related to oxygen concentrations, except for two samples collected just below the thermocline. In these two samples, the reactive phosphate concentrations were depleted relative to oxygen and phosphate was enriched on particulate matter. However, more numerous deviations from the inverse silicate-oxygen and nitrate-oxygen relationship were observed. High levels of $\mathrm{NH}_{4}$ and $\mathrm{NO}_{2}$ suggested that recently formed organic matter was in the process of being metabolized in the water column.

In the region of the shallow embayment at the landward end of the fjord, low particulate Mn concentrations (1000 ppm and high dissolved Mn concentrations ( $725 \mathrm{nM}$ ) were observed. In the region of the horizontal oxygen gradient seaward of the embayment, Mn pre-ipitates onto particles, resulting in particulate concentrations as high as $40,000 \mathrm{ppm}$. Particulate $\mathrm{Fe}$ in excess of that derived from aluminosilicates were highest in the embayment region and increased towards the bottom. Dissolved $\mathrm{Zn}$ was depleted in the surface waters $(2 \mathrm{nM})$ and increases in mid-depth water in direct proportion to phosphate concentrations up to $9 \mathrm{nM}$. Dissolved $\mathrm{Zn}$ concentrations decreased in the nearbottom region of high particulate $\mathrm{Fe}$. Dissolved $\mathrm{Cd}$ was also depleted in the surface and was elevated in mid-depth waters, although not to the extent observed for $\mathrm{Zn}$. In contrast to $\mathrm{Zn}$ and $\mathrm{Cd}$, the distributions of dissolved $\mathrm{Cu}$ and $\mathrm{Ni}$ were not significantly affected by biogeochemical processes.
\end{abstract}




\title{
BIOLOGICAL CONTROL OF CU PARTITIONING IN ESTUARIES
}

\author{
Anthony J. Paulson, Herbert C. Curl, Jr. and James F. Gendron \\ NOAA \\ Pacific Marine Environmental Laboratory \\ 7600 Sand Point Way, N.E. \\ Seattle, Washington 98115-0070 \\ USA
}

\begin{abstract}
In many estuaries, $\mathrm{Cu}$ is cunservative. To understand whether this observation can be attributed to a low equilibrium partition coefficient or a result of inert components of dissolved $\mathrm{Cu}$ that do not participate in biogeochemical reactions, ${ }^{64} \mathrm{Cu}$ was added to sets of suspensions containing four different samples of estuarine suspended matter. Comparisons of the partitioning of natural $\mathrm{Cu}$ and new radioactive $\mathrm{Cu}$ added in the ionic form were used to identify two components of natural $\mathrm{Cu}$ that did not completely equilibrate with the added ionic radioactive $\mathrm{Cu}$ : 1) $\mathrm{Cu}$ associated with hydrophobic dissolved organic matter and 2) $\mathrm{Cu}$ contained in the residual component of the particulate phase.

For each set of suspension, the suspended matter samples were suspended in two solutions: 1) filtered seawater and 2) filtered seawater in which the hydrophobic organic matter had been removed. An understanding of the importance of dissolved organic matter in controlling the partitioning of $\mathrm{Cu}$ between the dissolved and particulate phases was obtained by comparing the partitioning between these two suspensions within each set. For the suspensions containing abiotic sediment trap particles, the removal of hydrophobic dissolved organic matter resulted in a two-fold increase in the distribution coefficient $\left(\mathrm{K}_{\mathrm{p}}\right)$ of added radioactive $\mathrm{Cu}$ (from $10^{4.50} \mathrm{l} / \mathrm{kg}$ to $\left.10^{4.81}\right)$. The partitioning of ${ }^{64} \mathrm{Cu}$ in the suspensions was controlled by chemical equilibria dominated by complexation with particulate and dissolved organic matter.

In three similar sets of suspensions containing biotic particles, organisms indirectly controlled the partitioning of added $\mathrm{Cu}$ by excreting dissolved organic ligands and by coating particulate inorganic surfaces with organic matter that prevented equilibria between the surfaces and the solution. The behavior of natural $\mathrm{Cu}$ in these biotic suspensions indicate that the partitioning of $\mathrm{Cu}$ was controlled as much by active biological processes as by chemical equilibria.
\end{abstract}




\title{
TRACE METAL CYCLING IN THE OCHLOCKONEE RIVER/ESTUARY
}

\author{
Rodney T. Powell and William M. Landing \\ Department of Oceanography \\ Florida State University \\ Tallahassee, Florida $\mathbf{3 2 3 0 6}$ \\ USA
}

\begin{abstract}
$\underline{\text { Abstract }}$
A chromatographic separation scheme has been developed in order to study trace metal speciation. A significant advantage of this technique is its application to any element which can be determined by atomic absorption spectrophotometry. The scheme consists of size exclusion resin to trap colloids, anion exchange resin to collect organically complexed metals and a cation exchange resin to collect free metals and labile complexes. Experimental results indicate efficient trapping of 50-100 nm hematite $\left(\mathrm{Fe}_{2} \mathrm{O}_{3}\right)$ colloids by the size exclusion resin in low DOC freshwater and seawater. In addition, the DEAE anion exchange resin collects $\mathbf{6 0 - 8 0 \%}$ of the dissolved iron and $100 \%$ of the fluorescent humic materials from river water.

In the estuary, the humic fluorescence (emission wavelength $\mathbf{4 3 0} \mathrm{nm}$ and excitation wavelength $340 \mathrm{~nm}$ ) is conservative while dissolved iron is more than $85 \%$ removed before salinity 10. This would seem to indicate that the iron is not strongly bound by the humic matter or that the iron is colloidal. However, the results of kinetic experiments show that iron in river water is reduced at approximately the same rate as iron that is complexed with EDTA. Freshly precipitated amorphous iron hydroxide colloids are reduced at a rate that is approximately one half of either iron-EDTA complexes or iron in river water. Our results suggest that dissolved iron in river water is not present in the form of oxyhydroxide colloids, but instead appears to be complexed by DOC. However, the DOCFe fraction is removed at a different rate than the fluorescent humic material in the estuary.
\end{abstract}




\title{
REDOX-SENSITIVE ELEMENTS IN CHESAPEAKE BAY: BIOGEOCHEMICAL PROCESSES AND MODELING APPROACHES
}

\author{
Maria Lourdes San Diego-McGlone and Gregory A. Cutter \\ Department of Oceanography \\ Old Dominion University \\ Norfolk, Virginia 23529-0276 \\ USA
}

\begin{abstract}
Traditionally, estuarine flux calculations have assumed steady state and tidally averaged conditions. These assumptions cause two potential problems: (1) this approach is unable to resolve the mechanistic details of the processes involved and (2) estuaries are dynamic environments in which a wide range of biogeochemical processes occur on time scales of hours to months. Several processes can affect long-term (seasonal) and shortterm (hourly) variations in the chemical composition of an estuary, including biogeochemical reactions in the water column, advective transport, and diffusion from underlying sediments.

In order to closely examine the relative importance of these processes, studies were conducted in the Chesapeake Bay. A Lagrangian drifter was used to track a parcel of bottom water and allow monitoring of in situ water column processes and sediment-water exchange. In addition, a fixed (Eulerian) station was established to integrate these processes and evaluate advective transport. Porewater profiles were also utilized to calculate sediment-water exchange rates. Elements such as oxygen, sulfur, iron, manganese, nitrogen, phosphorus, arsenic and antimony were examined since they are affected by the Bay's changing redox conditions.

Results of estuarine modeling have shown that the total flux of materials within the estuary is strongly influenced by sediment-water exchange, particularly for ammonia (up to $96 \%$ ) and phosphate (up to $83 \%$ ). At the fixed station, large hourly variations in concentrations indicate that advection controls Eulerian behavior. From the Lagrangian study, maximum concentrations usually occur when the water mass passes over areas with higher benthic fluxes. An advection-diffusion model that simulates time-dependent concentration profiles of some redox species is being developed.
\end{abstract}




\title{
THE ROLE OF PARTICLES AND COLLOIDS IN THE TRANSPORT OF RADIONUCLIDES AND TRACE METALS IN ESTUARINE AND COASTAL ENVIRONMENTS
}

\author{
Peter H. Santschi and M. Baskaran \\ Department of Marine Science \\ Texas A\&M University \\ Galveston, Texas 77553-1675 \\ USA
}

\section{Abstract}

Trace metals, which are derived from crustal weathering, enter the ocean for the most part via rivers, but also via atmospheric fallout and hydrothermal fluids. Upon entering the ocean, they undergo rapid changes due to physicochemical processes. In estuarine and coastal environments, these processes include adsorption/desorption onto and from suspended particles, coagulation of colloidal material, as well as biologically mediated recycling between water column and sediments. A better understanding of the fate of trace metals in coastal areas must include the knowledge of the way these processes are coupled to each other. For example, a theoretical treatment of adsorption of metals must consider metal sorption onto particles of all sizes, including colloids, and not just onto larger settleable particles. A consequence of such an approach is that the kinetics of scavenging must include coagulation and sedimentation in addition to sorption (Honeyman and Santschi, 1989). In high energy dissipation environments such as estuaries and coastal embayments, particle coagulation can occur not only in the water column but also in the viscous sublayer above the sediment-water interface. Sedimentary scavenging furthermore must include other physically and biologically mediated processes such as particle resuspension into the water column and benthic mixing by bioturbation into the sediment column, which can both be coupled to the bacterially mediated redox cycling of $\mathrm{C}, \mathrm{N}, \mathrm{Mn}, \mathrm{Fe}$ and $\mathrm{S}$.

Observations of the partitioning of dissolved trace metals with particle phases in the laboratory and field indicate that the partition coefficient increases with decreasing particle concentrations. This is the "particle-concentration" effect. Such a behavior can be ascribed to colloidal phases which pass a $0.45 \mu \mathrm{m}$ filter, as it would not be expected from a purely thermodynamic description of these systems. Another indication of the presence and role of colloids is the particle concentration dependency of scavenging rate constants (Honeyman and Santschi, 1989, 1991). These coagulation processes can significantly affect our ability to estimate the self-cleaning capacity of the coastal water (Honeyman and Santschi, 1988) by underestimating removal efficiencies when extrapolating data from laboratory experiments to natural systems. Experimental validation of the proposed mechanism involves the identification of hydrolytic metals in colloidal phases, a physical, chemical, biological and sedimentological characterization of these phases, as well as a determination of their age.

In this presentation, we will discuss field observations from Galveston Bay to the open Gulf of Mexico. They will include measurements of the colloidal associations of hydrolytic ${ }^{234} \mathrm{Th}$ and the relationships of its colloidal fraction with particle concentrations and with calculated scavenging rate constants. These relationships also provide an alternative way for calculating particle residence times.

The initial success of the colloidal pumping model in explaining a number of seemingly odd observations of $\mathrm{Th}$ behavior in the ocean is encouraging. However, we realize from our observations of the variability of partition coefficients of natural radionuclides that improved models need to consider the chemical and biological nature of these particles and the variability in their surface characteristics. 


\title{
HEAVY METALS IN THE ELBE RIVER ESTUARY, WITH A LOOK AT A TURNING POINT IN HISTORY AND ENVIRONMENTAL POLITICS
}

\author{
Diether Schmid' \\ Bundesamt fur Seeschiffahrt und Hydrographie \\ Labor Sulldorf \\ Wustland 2 \\ W 2000 Hamburg 55 \\ Germany
}

\begin{abstract}
$\underline{\text { Abstract }}$
Concentration changes of $\mathrm{Hg}, \mathrm{Cd}, \mathrm{Cu}, \mathrm{Fe}, \mathrm{Mn}$, and $\mathrm{Ni}$ in the water phase of the Elbe River were investigated on two cruises in August 1983 and again in June 1985. Stations covered the full range of the estuary, from riverine water (Port of Hamburg) through the lower Elbe River course to the open North Sea (German Bight). The same methods for sampling and analysis were used, making data readily comparable. Concentrations go down by $2 \ldots 3$ orders of magnitude, from Hamburg to the sea. Plotted against salinity, all metals show an exponential decrease.

Historical events in 1990, particularly the reunification of Germany and the political change in Czechoslovakia, can be expected to deeply influence the detrimental situation of heavy metal pollution in the Elbe River and estuary. Data on heavy metal emissions and concentrations have become available that had been kept top secret previously. Pollution sources in Eastern Germany have become transparent. Drastic changes in the metal pollution are occurring presently; substantial financial means have been appropriated, and huge environmental efforts have been decided upon that should improve the situation during the coming years. Since the Elbe has been considered the major river with the highest mercury pollution load in the world, emphasis is placed particularly on the reduction of inputs of mercury.
\end{abstract}




\title{
TRACE ELEMENTS IN THE OUTFLOW REGION OF THE MISSISSIPPI RIVER: COMPARISON OF THE MISSISSIPPI AND ATCHAFALAYA PLUMES
}

\author{
Alan M. Shiller \\ Center for Marine Science \\ University of Southern Mississippi \\ Stennis Space Center, Mississippi 39529
}

USA

\begin{abstract}
The Mississippi River outflow region provides a unique opportunity for studying estuarine trace element chemistry. The reason for this is that essentially the same fluvial endmember discharges into two very different estuarine environments. The bulk of Mississippi River water flows down the main channel of the river to the birdfoot delta; however, about a third of the river water is released through the Atchafalaya River which enters the Gulf of Mexico through a bay some $75 \mathrm{~km}$ west of the delta. An additional factor of interest is the seasonal development of bottom water hypoxia or anoxia in certain shallow regions of the Louisiana shelf below parts of the mixing zone. We have examined trace element distributions in the outflow region from the delta west to the Texas border. Surprisingly, our initial results show no apparent influence of the hypoxia region on trace element distributions. However, differences are seen between the delta and Atchafalaya mixing areas. Specifically, extrapolated river endmember concentrations in the Atchafalaya region appear to be lower than actual river concentrations, whereas this is not the case in the delta region. We speculate that this difference arises because Atchafalaya River water loses much of its suspended load in the broad, shallow Atchafalaya Bay before appreciable mixing with seawater has occurred. Primary production can thus occur at very low salinities. In the delta region, however, suspended loads can remain high until intermediate salinities; thus, substantial primary production does not occur until these intermediate salinities.
\end{abstract}




\title{
ESTIMATION OF BIO(BEOCHEMICAL BARRIERS EFFECT ON \\ TRACE METALS MI(BRATION ON THE RIVER-SEA SYSTEM
}

\author{
E.N. Shumilin, V.V. Anikiev, N.A. Goryachev, A.P. Kasatkina, \\ A.P. Kotlyarova, S.M. Fazlullin, M.P. Pak, M.P. Mironenko \\ and E.(i. Starodubtsev \\ Pacific Oceanological Institute \\ Far Eastern Division \\ U.S.S.R. Academy of Sciences \\ 7 Radio Street \\ Vladivostok, 690032 \\ USSR
}

\section{Abstract}

Chemical elements introduced into the marine environment by river discharge pass on their way a number of specific areas where the intensity of their migration changes considerably. Different metals as well as the species of the same element may undergo a number of changes resulting from biogeochemical barriers influence. The spatialtemporal characteristics of such barriers depend on both environmental factors (hydrodynamic, hydrochemical and biological) and individual chemical properties of the element or metal species behaviour.

The example of such a barrier zone is the Razdolnaya River estuary (Amur Bay, Sea of Japan), where the active removal of humic and fulvic acids, Fe dissolved and $\mathrm{Fe}$, $\mathrm{Cu}, \mathrm{Mn}, \mathrm{Ni}$ particulate forms were revealed in $0.5 \%$ salinity range mainly. Usually a biological barrier is situated in the sea zone of an estuary, its role increases in the period of phytoplankton blooming, when the correlation of $\mathrm{Zn}$ and $\mathrm{Pb}$ content in sestone with fluctuations in primary production was observed. The studies of trace metals accumulation by zooplankton in the area of the greatest primary production revealed that the most active TM accumulator in Amur Bay were chitin-containing plankters, especially those with underdeveloped secretory systems or which had no system at all. On the contrary, young fish with well developed secretory systems were not observed to accumulate trace metals.

The physico-chemical type of barrier zone was registered in the mixing zone of acidic volcanogeneous waters of the Yuriev River (pH 1.8) with the Okhotsk Sea waters. Hydrolysis was the main mechanism of iron transformation from dissolved fraction into particulate one which took place with the increase of $\mathrm{pH}$ up to 3-5. The formation of the particulate fraction of other elements occurred in the sea part of mixing zone within 6-8 pH range.

The important role of biogeochemical barrier zones for TM migration in river-sea systems is shown also for the Amur, Yangtze, Mekong and Nile river estuaries. 


\title{
ASPECTS OF THE GEOCHEMISTRY OF THE MESOTIDAL CHANGJIANG RIVER THROUGH THE DISTRIBUTIONS OF SUSPENDED HYDROCARBONS AND PAHS
}

\author{
M.A. Sicre, I. Broyelle, A. Lorre, and A. Saliot \\ Laboratoire de Physique et Chimie Marines \\ Universite Pierre et Marie Curie \\ Tour 24-25, 5 ème étage, $4 \mathrm{Pl}$. Jussieu \\ 75252 Paris cedex \\ France
}

Abstract

Hydrocarbons (HCs) and polycyclic aromatic hydrocarbons (PAHs) were investigated on the suspended particles of the mixing zone of the Chang Jiang estuary to assess the fate of allochtonous material in this mesotidal estuarine system. Samples were acquired at the mooring station 8806 over two tide cycles to ascertain qualitative and quantitative changes taking place upon flood and ebb currents.

Flooded waters exhibited an increase in total suspended particles (TSP) and salinity due to the landward transport of suspended solids from the turbidity maximum zone originally present further out in the estuary. HC assemblages indicated major terrestrial and anthropogenic inputs whereas PAH fingerprints pointed out that incomplete pyrolytic combustions, generated by coal-fired furnace emissions, were the primary sources contributing to this compound series. Saltier waters of the Taiwan Warm Current containing noticeably lower amounts of TSP and displaying a more pronounced marine character could reach the mooring site at the final stage of the flood. During the ebb, TSP, HC and PAH concentrations were lower but $\mathrm{HC}$ and $\mathrm{PAH}$ compositional features remained similar as in the flooded waters. However superimposed to this trend, secondary TSP events, presumably related to the Huang Pu waters flushing into the Chang Jiang, were observed. During such events the $\mathrm{HC}$ signature was different reflecting urban discharges via the Huang Pu river crossing the highly populated and industrialized area of Shanghai.

Concentrations expressed as a function of the suspended loading were low in the turbidity maximum, and even lower when originating from the Hang Pu River, compared to the ebb waters. Based on very few existing data it was quite unusual to find comparable concentration levels for $\mathrm{HCs}$ and PAHs. This finding was attributed to the high affinity of PAHs towards silt-clay particles and to their microbial refractivity relative to $\mathrm{HC}$, leading to an accumulation of the former in estuarine particles whose residence time in the turbidity maximum otherwise contributes to the enhancement of this phenomenon.

Instantaneous flux calculations based on current meter data suggested that flood transport was quantitatively more important during high TSP events. Ebb transport was found to be less significant because of lesser amounts of particles involved and weaker current velocities. Nevertheless, this was partly compensated by a more efficient transport per particle due to a higher $\mathrm{HC}$ and PAH content of ebbed particles. A major consequence of this was that effluents from the Huang Pu would hardly be eliminated from the river mouth and would consequently be trapped in the estuarine circulation.

Additional sampies were acquired in the north and south channels of the river to assess spatial heterogeneities. The observed variations in $\mathrm{HC}$ and PAH compositions and concentrations agreed with the flow pattern and dynamical features of the estuary. 


\title{
CONCENTRATION OF DISSOLVED MAJOR ELEMENTS IN THE LENA RIVER AND ITS DELTA
}

\author{
I.S. Sidorov' and V.V. Gordeev ${ }^{2}$ \\ 'State Hydrometeorological Survey of USSR, Department of Tiksi \\ ${ }^{2}$ P.P. Shirahov Institute of Oceanology, USSR Academy of Science \\ USSR
}

\begin{abstract}
$\underline{\text { Abstract }}$
The Lena River is the eighth world river in terms of water discharge $\left(525 \mathrm{~km}^{3} \mathrm{y}^{-1}\right)$ and the second one's discharging to the Soviet Arctic, after the Yenissel.

The sediment discharge of the Lena River is $\mathbf{1 7 . 6}$ million tons $\mathrm{y}^{-1}$ (i.e. an average turbidity of $\left.34 \mathrm{mg} \mathrm{l}^{-1}\right)$. The observations on the major element content in the lower stream of the river started in 1935 . In this work the generalization of data about chemical composition of the Lena River waters in different areas of its drainage basin including some of its tributaries is given. Average mineralization changes during the year from $60-70 \mathrm{mg} \mathrm{l}^{-1}$ during the flood (June-July) up to $300-330 \mathrm{mg} \mathrm{l}^{-1}$ in low discharge (March-April). Along with mineralization the class/or type of waters is changing too. The greater part of the year hydrocarbonates and calcium ions dominate in the low stream of the River. During winter time, when water mineralization exceeds $250 \mathrm{mg} \mathrm{l}^{-1}$ Lena's waters are transformed to chloride class with sodium and potassium predominating over calcium. The reason is due to the increasing role of groundwater input. The chemical composition of groundwaters is mainly controlled by the widespread limestone and dolomite deposits in the upper and middle reaches of the River.

The plot of variations of major ion concentrations against total mineralization showed that the hydrochemical boundary between river and sea waters is located at $2 \%$. The Lena River system transports annually about $\mathbf{4 7 . 5}$ million tons of dissolved salts to the Laptev Sea, corresponding to an average chemical denudation of $19 \mathrm{t} . \mathrm{km}^{-2} \mathrm{y}^{-1}$ which is twice lower than the global average.
\end{abstract}


THE VERTICAL FLUX OF TOTAL PARTICULATES AND ORGANIC MATTER IN THE LOWER ST. LAWRENCE ESTUARY: TIME AND SPACE PATTERNS AND BIOGEOCHEMICAL RESPONSES IN THE UNDERL, YING SEDIMENT

\author{
Norman Silverberg \\ Institut Maurice-Lamontagne \\ Fisheries and Oceans \\ P.O. Box 1000 \\ Mont-Joli, Quebec G5H 3Z4 \\ Canada
}

(Abstract not submitted in time for publication) 


\title{
A 200 YEAR RECORD (F ANNUALLY MODULATED DEPOSITIONAL EVENTS RECORDED IN THE SEDIMENTS OF THE SAGUENAY FJORD, QUEBEC
}

\author{
John Norton Smith' and Charles T. Schafer ${ }^{2}$ \\ 'Marine Chemistry Division \\ Bedford Institute of Oceanography \\ Dartmouth, Nova Scotia B2Y 4A2 \\ Canada \\ ${ }^{2}$ Atlantic Geoscience Centre \\ Bedford Institute of Oceanography \\ Dartmouth, Nova Scotia B2Y 4A2 \\ Canada
}

\begin{abstract}
The 20th Century geochronology for a $5 \mathrm{~m}$ piston core collected from an anoxic, high sedimentation $(>2.5 \mathrm{~cm} / \mathrm{y})$ regime near the head of the Saguenay Fjord, Quebec has been established to a resolution of better than $1 \mathrm{y}$ using a constant flux, ${ }^{210} \mathrm{~Pb}$ model. This geochronology has been extended into the 18th and 19th century sections of the core through the application of a constant organic flux model. Interannual variations in the sedimentation rate on the order of $50 \%$ are caused by pulsed inputs of silt and fine sand during the Spring freshet of the Saguenay River. The annual sand flux to the sediments at the mouth of the river is associated with the maximum Spring (mean monthly) discharge through the Saguenay River for the period, 1914-1982 ( $r=0.74 ; n=68)$. Calibration of the mechanism linking river discharge to sand flux for the 20th Century permits the reconstruction of a proxy river discharge record based on sand flux data for the 18th and 19th century intervals of the core. The proxy (paleo) discharge record for the Saguenay River suggests that Spring river discharge levels were characterized by a higher amplitude of variation in the 18th and 19th centuries compared to that evident in the 20th Century. This paleo-discharge model provides a new method for the historical reconstruction of climatological events through textural analyses of precisely dated, estuarine sediments.
\end{abstract}


GEOCHEMICAL STUDIES IN THE GODAVARI ESTUARY, INDIA

B.L.K. Somayajulu', D.V. Borole, D. Eisma, J.-M. Martin,

K.S. Rao, and A.J. Thomas

'Physical Research Laboratory, Navrangpura, Ahmedabad 380009 , India

(Abstract not submitted in time for publication) 
HUMIC MATTER EXTRACTED FROM THE ZAIRE ESTUARY

\author{
Alejandro Spitzy \\ Max-Planck-Institut fur Meterologic \\ Bundesstr, 55 \\ D-2000 Hamburg 13 \\ Germany
}

(Abstract not submitted in time for publication) 


\title{
GEOCHEMICAL ASPECTS OF METAL BIOAVAILABILITY: AN OVERVIEW OF SEDIMENT GEOCHEMISTRY
}

\author{
Bjorn Sundby \\ Maurice-Lamontagne Institute \\ Department of Fisheries and Oceans \\ Box 1000 \\ Mont-Joli, Québec \\ Canada
}

\begin{abstract}
The main problem in determining the effects of contaminated sediments on benthic organisms is the difficulty of knowing precisely what the organisms are exposed to. The difficulty is not only related to analytical chemistry and speciation, but also to the heterogeneous and dynamic nature of the sedimentary environment. The concentration of a trace element in the pore water or in the bulk sediment, for example, can differ by orders of magnitude between the surface and a few centimetres depth. The vertical distribution of a trace element can also vary in time and space as a result of biological events in the water column and patchiness in the sediment. The benthic organisms themselves interact with the sediment and modify the chemical composition of their immediate environment. Construction and irrigation of burrows is one example. Mixing the sediment is another. Hence meaningful statements of exposure can only be made on the basis a clear understanding of the sedimentary environment and the organisms' relationship to it. In this paper, I will give an overview of our present uncierstanding of biogeochemical process in fine grained sediments, based on studies of early diagenesis in the St. Lawrence estuary.
\end{abstract}




\title{
THE PHOSPHORUS CYCLE IN IRON RICH COASTAL MARINE SEDIMENTS: PHOSPHATE BUFFERING AT WORK
}

\author{
Bjorn Sundby, 'Charles Gobeil, ${ }^{1}$ Norman Silverberg,' \\ and Alfonso Mucci $^{2}$ \\ 'Department of Fisheries and Oceans \\ Maurice-Lamontagne Institute \\ P.O. Box 1000 \\ Mont-Joli, Québec G5H 3Z4 \\ Canada \\ 2Department of Geological Sciences \\ McGill University \\ Montréal, Québec H3A 2A7 \\ Canada
}

\begin{abstract}
The sedimentation flux of phosphorus and the distribution of phosphorus in sediment and sediment pore water were measured in the $325 \mathrm{~m}$ deep Laurentian Trough in the Gulf of St. Lawrence. Adsorption/desorption experiments were carried out on fresh surface material.

Two thirds of the sedimentation flux of phosphorus are buried, and one third is returned to the overlying water. Pore water profiles in more than twenty cores taken at different times and at different locations in the Trough show a virtually constant phosphate concentration of $6 \mu \mathrm{M}$ in the top few $\mathrm{cm}$ of the cores in spite of a two orders of magnitude concentration range deeper in the cores. In consequence, the concentration difference across the sediment-water interface, which drives the flux of regenerated phosphate, appears to be constant in time and space. laboratory experiments showed that the constant phosphate concentration in the pore water near the sediment surface is maintained by sorption/desorption reactions with the surface sediment, which has a high adsorption capacity for phosphate. Thus, sorption equilibria control the concentration of phosphate in the sediment pore water and regulate the flux of phosphate to the bottom water.
\end{abstract}




\author{
SUSPENDED-SEDIMENT RESPONSE TO RIVER FLOOD, \\ SEMI-DIURNAL AND FORTNIGHTLY TIDAL VARIATIONS \\ IN A MESOTIDAL UPPER ESTUARY: SADO ESTUARY, PORTUGAL \\ Carlos Vale, Carlota Cortesao, Odete Castro, and Ana M. Ferreira \\ Instituto Nacional de Investiagaçao das Pescas \\ Av. Brasilia 1400 \\ Lisboa \\ Portugal
}

\begin{abstract}
Among the more important sedimentological functions of estuaries is to mix and dilute fluvial sediments, and to provide a natural receiving basin for the accumulation and storage of fluvial sediments which are often contaminated. However, determination of sediment retention may be difficult when suspended-sediment concentration field is very unstable, such as in the Sado estuary a meso-tidal estuary sensitive to river flood. Thus, episodic events like runoff storm, are an unusual opportunity to document the impact of sharp increase of freshwater inflow, and associated sediments, in the upper part of an estuary.

The chief objective of this study is to understand the mechanisms governing the suspended sediment in the upper Sado estuary, and the importance of the annual river flood on the escape of fluvial suspended sediment from the upper estuary. To approach these objectives, surveys were carried out at high and low tide in different semi-diurnal tide ranges every month for one year, including contrasting freshwater discharge. Total DDT was used as a tracer of the derived-flood material in the upper estuary.
\end{abstract}




\title{
CD/CA RATIOS IN FORAMINIFERAL SHELLS FROM SAN FRANCISCO BAY: A RECORD OF ESTUARINE CHEMISTRY
}

\author{
A. van Geen and S.N. Luoma \\ Water Resources Division \\ U.S. Geological Survey \\ 345 Middlefield Road \\ Menlo Park, CA 94025 \\ USA
}

\section{$\underline{\text { Abstract }}$}

Dissolved Cd concentrations in San Francisco Bay (ranging from 0.5 to 1.3 $\mathrm{nmol} / \mathrm{kg}$ ) are elevated relative to the composition of the two principal end-members contributing to the estuary: the Sacramento River $(0.08 \mathrm{nmol} / \mathrm{kg})$ and Pacific coastal water $(0.2-0.4 \mathrm{nmol} / \mathrm{kg})$. To determine whether such enrichments are natural or anthropogenic, we are developing a new approach to obtain a proxy-record of dissolved $\mathrm{Cd}$ in the Bay. The key to such a reconstruction is the demonstration by E.A. Boyle (1988, Paleoceanography 3, 471-489 and references therein) that the $\mathrm{Cd} / \mathrm{Ca}$ ratio in the shell of certain benthic foraminifera, after rigorous cleaning of non-calcite phases, is a linear function of bottom water $\mathrm{Cd}$ concentration at the time of shell formation.

Our data indicate that $\mathrm{Cd} / \mathrm{Ca}$ ratios of recent Eiphidiella hannai, a coastal and estuarine foraminifer found from California to Alaska, reflect ambient $\mathrm{Cd}$ concentrations. $E$. hannai is also the dominant species throughout a $2.4 \mathrm{~m}$ long sediment core from San Francisco Bay. Preliminary results show a downcore decrease in foraminiferal $\mathrm{Cd} / \mathrm{Ca}$ suggesting a man-induced enrichment. However, the detailed timing of such variations must be established to distinguish between two possible mechanisms: (1) increasing Cd inputs to the Bay and (2) increasing diversion of fresh water to agriculture.

We will also briefly discuss how $\mathrm{Cd} / \mathrm{Ca}$ variations in $E$. hannai could be used to test GCM predictions of changing wind patterns along the California coast during glacial/interglacial cycles. 


\title{
DETERMINATION AND CHARACTERIZATION OF ORGANIC MATTER IN THE KRKA ESTUARY
}

\author{
Vjerocka Vojvodic,' Bozena Cosovic,' and Gustave Cauwet ${ }^{2}$ \\ ${ }^{1}$ Ruder Boskovic Institute \\ Center for Marine Research \\ Zagreb, Croatia \\ Yugoslavia \\ ${ }^{2}$ Universite de Perpignan \\ Centre de Research de Sedimentologie Marine \\ Perpignan \\ France
}

\section{$\underline{\text { Abstract }}$}

Surface active substances (SAS) were investigated in the well stratified Krka estuary with generally low concentration of organic matter by using an electrochemical method and different procedures of fractionation.

The following procedures of fractionation of the complex mixture of organic solutes were performed in order to characterize organic matter of estuarine samples:

- Fractionation to heterodispersed and dissolved fraction by filtration using Whatman GF/F fiberglass filters $(0.7 \mu \mathrm{m})$,

- Fractionation of dissolved organic material by ultrafiltration into real solution-fraction, i.e. fraction of solutes of size less than $10 \mathrm{~mm}$ and fraction enriched with colloids with size of solutes higher than $10 \mathrm{~mm}$ and less than $0.7 \mu \mathrm{m}$,

- Fractionation of dissolved fraction as well as real solution-fraction by sorption on XAD-8 resin at $\mathrm{pH}=2$, based on hydrophobic-hydrophilic properties gives hydrophobic acid fraction adsorbed at $\mathrm{pH}=2$ and hydrophilic fraction which is not sorbed on the resin.

Surfactant activity (SA) of organic matter of the original (nontreated) sample and of different fractions was expressed in terms of equivalents of the model substance, TRITON-X-100.

Particulate organic carbon (POC) and dissolved organic carbon (DOC) in estuarine samples were measured too.

(Continued on next page) 
The content and composition of $S A S$ in the Krka estuary vary seasonally, with low values in winter and high values in summer and autumn. The most frequent surfactant activity values are similar to the values found in coastal zones in the Adriatic Sea and zones of higher biological activity.

The accumulation of SAS with mostly hydrophobic properties occurs in the mixing zone of fresh and saline water along the vertical profile. Surfactant activity in saline water layer is stable and very low. At fresh/saline interface and in fresh water layer quantitative changes as well as qualitative changes of chemical composition of present organic matter were observed in the period of 24 hours indicating various transformation processes.

Heterodispersed fraction was found as the most reactive part of POC contributing to the surfactant activity in the mixing zone of the estuary. In marine and estuarine waters, depending on the biological activity, the heterodispersed fraction may have important contribution to the surfactant activity and adsorption behaviour of present organic matter.

Fractionation of dissolved organic matter by the used ultrafiltration procedure showed that surfactant activity of colloidal fraction is in the range from 20 to $50 \%$ of the total surfactant activity of the dissolved fraction of organic matter.

Fractionation of dissolved organic material by sorption on XAD-8 resin showed that negatively charged organic substance adsorbable at $\mathrm{pH}=2$, i.e., with hydrophobic properties at these conditions are predominant. The same results were obtained for real solutionfraction. Hydrophilic surface active substances are usually less than $20 \%$ of surfactant activity of the estuarine samples.

In original estuarine samples containing heterodispersed and dissolved fraction, hydrophobicity is the predominant property of present organic matter at natural conditions due to the significant contribution of the heterodispersed fraction. On the contrary dissolved fraction, as well as real solution-fraction, comprising mainly of hydrophobic acid and hydrophilic components shows hydrophilic properties under conditions of natural $\mathrm{pH}$.

The nature and role of colloidal organic matter in adsorption processes in the Krka estuary is still not well known and presents the subject of our ongoing studies.

(Author unable to be present at Symposium) 


\title{
LONG TERM TRENDS OF TRACE METALS IN THE GÖTA RIVER ESTUARY
}

\author{
Stig Westerlund, Conny Haraldsson and Marianne Pollak \\ Department of Analytical and Marine Chemistry \\ University of Göteborg and Chalmers University of Technology \\ S-41296 Göteborg \\ Sweden
}

\begin{abstract}
The Göta River is the largest river on the Swedish west coast $\left(500 \mathrm{~m}^{3} / \mathrm{s}\right)$. This river enters the sea in a salt wedge type estuary. The river is draining Lake Vänern, the largest lake in Sweden. The drainage area for this river system is in a highly populated and industrialized part of Sweden.

The first study of the trace metals $\mathrm{Cd}, \mathrm{Cu}, \mathrm{Ni}, \mathrm{Pb}, \mathrm{Fe}$ and $\mathrm{Zn}$ in this estuary were made in 1980. This study showed that the Göta River estuary was not heavily polluted. The trace metal concentrations found in the fresh water endmember were in the range typical for fresh water in the industrialized part of Scandinavia. Since then the Göta River estuary has been studied yearly to 1989 to evaluate the long term trends for the trace metals $\mathrm{Cd}, \mathrm{Cu}, \mathrm{Fe}, \mathrm{Mn}, \mathrm{Ni}, \mathrm{Pb}$ and $\mathrm{Zn}$.

Large efforts have been undertaken in the last decade to decrease the emission of heavy metals in Sweden, particularly for cadmium. The introduction of lead-free gasoline should also highly influence this estuary with respect to lead. The purpose of this study of the Göta River estuary is to evaluate if the decrease in emission of the metals $\mathrm{Cd}, \mathrm{Cu}$, $\mathrm{Ni}, \mathrm{Pb}$ and $\mathrm{Zn}$ can be seen as a long term trend in this estuary. To evaluate possible variations caused by seasonal variation, a two-year study of the fresh water endmember and Lake Vänern during all seasons is also included in this work.
\end{abstract}




\title{
REDISTRIBUTION OF FINE PARTICLES DURING SEA LEVEL RISE
}

\author{
Herbert L. Windom \\ Skidaway Institute of Oceanography \\ P.O. Box 13687 \\ Savannah, GA 31416 \\ USA
}

\begin{abstract}
$\underline{\text { Abstract }}$
Along the southeastern Atlantic Coast of the United States there has been a continual redistribution of fine particles in sediments of the ocean margin since the last glacial maximum. During the glacial-interglacial time scale, the delivery of fine sediment to the continental slope changed from a direct cross-shelf input pathway to a more indirect pathway that involved southward alongshore transport. As the ocean transgressed the continental shelf, fine particles, previously deposited on the shelf, were moved shoreward and either trapped in estuaries or entrained in a southward directed alongshore transport system.

On decadal time scales, the present rate of sea level rise results in a decrease in the rate of fine-particle accumulation in nearshore sediments as estuaries become more efficient sedimentary traps.
\end{abstract}




\title{
THE ESTIMATION OF NATURAL AND ANTHROPOGENIC FLUXES OF \\ PARTICULATE TRACE ELEMENTS IN THE SCHELDT ESTUARY
}

\author{
Professeur Roland Wollast \\ University of Brussels \\ Laboratory of Chemical Oceanography \\ Brussels \\ BELGIUM
}

\begin{abstract}
The sediments present several advantages for monitoring contaminants in aquatic systems. Heavy metals, pesticides, and hydrocarbons show a high affinity to particulate matter and are consequently enriched in bottom sediments of estuaries and coastal areas adjacent to industrial and urban areas. They are, however, preferentially associated with fine grained suspended solids and colloidal organic and inorganic particles. It is therefore essential to understand and normalize for the effect of grain size distribution before the effect of anthropogenic inputs can be realistically evaluated.

A detailed study of the content of heavy metals in suspended matter and in sediments has been carried out in the heavily polluted estuary of the Scheldt. The distribution of metals as a function of the size fraction has been performed for the less than $65 \mu \mathrm{m}$ fraction of suspencied matter and sediment. Also, normalization techniques with respect to various components have been tested.

A tentative normalization technique to evaluate the concentrations of contaminants in sediments with respect to background or natural levels expected for similar noncontaminated deposits will be presented. Excess levels above background values are used to establish sediment quality criteria.

This approach allows also to improve the understanding of the evolution of suspended matter in the mixing zone of fresh water and sea-water, as well as the relations between suspended matter and deposited sediments.
\end{abstract}




\title{
INPUT OF METALS TO THE NORTH ATLANTIC FI?OM TWO LARGE CANADIAN ESTUARIES
}

\author{
P.A. Yeats \\ Physical and Chemical Sciences \\ Department of Fisheries and Oceans \\ Bedford Institute of Oceanography \\ P.(). Box 1006 \\ Dartmouth, Nova Scotia B2Y 4A2 \\ Canada
}

\begin{abstract}
The freshwater discharge from the Gulf of St. Lawrence and Hudison Bay accounts for more than $80 \%$ of the total freshwater discharge from eastern Canada and $70 \%$ of the total discharge from the eastern seaboard of North America. If the Gulf of Mexico is included, the Gulf of St. Lawrence/Hudson Bay discharge is still more than half of the total.

Both the Gulf of St. Lawrence and Hudson Bay have some distinctly estuarine characteristics and discharges of metals can be estimated using estuarine models. For Al, $\mathrm{Mn}, \mathrm{Fe}, \mathrm{Co}, \mathrm{Ni}, \mathrm{Cu}$, and $\mathrm{Zn}$, the distributions can be described by simple, highly significant, relationships with salinity. These regressions can be used in conjunction with knowledge of water discharges to estimate net metal inputs to the North Atlantic from these two systems. Cadmium distributions cannot be described by simple relationships with salinity so transports cannot be estimated so easily.

Most of the discharge from the Gulf of St. Lawrence nows along the Scotian Shelf to the Gulf of Maine. Metal-salinity relationships can also be used to estimate metal transports through this region for some metals. The applicability of this estuarine model, however, tends to break down as the oceanography becomes more complex and metal distributions are determined more by oceanic rather than estuarine processes.
\end{abstract}




\title{
PROPOSED HANGZHOU BAY AND THE QIANTANG ESTUARY AS THE RIVER SYSTEM FOR STUDY ON RIVER INPUTS (OF NUTRIENTS TO THE MARINE ENVIRONMENT IN THE WESTPAC REGION
}

\author{
Yu Guohui \\ Second Institute of Oceanography \\ National Bureau of Oceanography \\ Hangzhou, Zhejiang 310005 \\ People's Republic of China
}

\begin{abstract}
General. The Hangzhou Bay area is located on the coast of Zhejiang Province which is on the Southeast Coast of China. The Province has an area of more than $100,000 \mathrm{~km}^{2}$, a coast $2200 \mathrm{~km}$ long, over 2000 off-shore islands and a total population of over 40 million people, half of which live in the coastal zone. The area of the bay is roughly $10,000 \mathrm{~km}^{2}$. On the north of the bay is the deltaic Hangia Plain, while on the south are the Ningshao and Yaobei plains.

Five of Zhejiang's eight administrative regions are located on these plains and three counties of Shanghai City are also located in the area of the Hangjia Plain. These eight administrative regions in Hangzhou Bay by population are ca 20 million. The cities such as Hangzhou, Ningbo, Jiaxing, Zhousan . . ., all have relatively high levels of industrial development, technical knowledge and experience in import-export.

Geology. The Hangia Plain is an alluvial lowlands composed primarily of sediment deposited by the often-flooding Changjiang River. The southern Ningshao and Yaobei plains are likewise composed of alluvial deposits but of an older type.

The southern hilly lands are composed of a combination of ancient highly folded and faulted pre-cambrian and Jurassic rocks intruded by later cretaceous granite.

Some $75 \%$ of the bay's bottom sediments are fine silt, especially on the north and near the head of the bay with medium silts in the south. Sea-derived sediments are mainly medium and fine silts. Sediment discharge from the Changjiang Estuary also greatly influence Hangzhou Bay sediments.

Topography. The form of the bottom changes gently with most of it being between 5 and $15 \mathrm{~m}$ deep and a mean depth of 10 meters. Due to the shallowness of the bay and its openness of the sea, the amount of sea water moving landward far exceeds inflowing
\end{abstract}


river water from the Qiantang River. As a result, the volume of the tidal prism of the Qiantang Estuary is very large, one reason for the great tidal range (annual average of $5.45 \mathrm{~m}$ ). Also, because the riverbed rise abruptly near the mouth of the Qiantang River, the famous Qiantang tidal bore reaching 3 meters in height is formed, a natural phenomena of considerable scenic value. The Zhousan Islands located just outside the Hangzhou Bay form a kind of natural defense for the bay. Because of their proximity to each other, the Zhousan Sea region has the strongest tidal flow in China.

Surface Hydrology. The Hangzhou Bay region is part of the so called "Pacific catchment area." The Qiantang River which drains into Hangzhou Bay has a length of $494 \mathrm{~km}$ and drains a catchment of $54349 \mathrm{~km}^{2}$. It is the largest river in Zhejiang Province. Most of the river's trunk and branch streams are navigable. Other rivers in this area include the Yangiang draining the Ningbo Plain and the Cao'e flowing from Hsin Chang in the south northward into the bay near Shangyu. On the northern Hangia plain is the world famous Grand Canal (Beijing-Hangzhou Canal) which was a giant irrigation project in ancient China.

Climate. Both Zhejiang Province and the Shanghai portion of the Changjiang delta plain have a sub-tropical monsoon climate with four distinct seasons.

The annual average temperature of Hangzhou City and Shanghai City are $16.1^{\circ} \mathrm{C}$ and $15.7^{\circ} \mathrm{C}$ respectively. Hangzhou being lightly warmer, has $20 \%$ more precipitation and a few days of high winds. These differences, among others, account for local variations in crop planting and harvesting, etc.

Present Status of Pollution Load. Since 1978 major changes have occurred in the Chinese economy especially in the coastal zone of this country which have produced increases in the rate of urbanization. Those are due to increases in agricultural efficiency, thereby producing a labour surplus $i$ : rural areas, and with increased need for labour in urban areas for services and developing industry. Under these pressures the regulation to restrict migration from rural to urban areas could not be strictly enforced, consequently the population in urban areas has increased markedly since 1978 .

One of the major consequences of the urban population growth concerns water usage and waste discharge. At this time there appears to be evidence that the discharge of domestic and industrial wastes is affecting the Hangzhou Bay and its adjacent coastal waters. As in the case of most heavily urbanized coastal waters, Hangzhou Bay is faced with the problem of eutrophication. It is reported that red tide has occurred near Zhousan fishing ground almost every May in the past few years. Therefore, if the present practices are not addressed now, it has the potential of becoming a very serious environmental problem in the foreseeable future. 


\title{
EPISODIC EVENTS IN THE STRATIFIED KRKA ESTUARY \\ (EAST ADR!ATIC)
}

\author{
V. Zutic \\ Center for Marine Research \\ "R. Boskovic" Institute \\ P.O.B. 1016 \\ YU.41001 Zagreb \\ Yugoslavia
}

\section{Abstract}

Three episodic events recorded since 1983 will be described.

The subsurface bloom of the marine dinoflagellate Gonyaulax polyhedra was observed on 19 October 1988 as a $6 \mathrm{~m}$ thick red-brownish layer. The layer was located below the halocline. The bloom was initiated by excystment in shallow parts of the upper reach of the estuary, where temperature near the bottom exceeded $20^{\circ} \mathrm{C}$. The autumn of 1988 was exceptionally dry, the river inflow was small and the brackish upper layer was $2 \mathrm{~m}$ thick and transparent. The exchange rate of water in the marine layer was at its lowest in the year. The supply of nutrients for growth came from sinking and decomposition of freshwater phytoplankton at the halocline and in the marine layer.

Hypoxia develops regularly near the bottom in autumn. At this time of the year temperature is at its highest in the marine layer. When in October, 1988 the extensive marine bloom appeared, the decomposition of the bloom drove the oxygen concentration below $1 \mathrm{mg} / \mathrm{l}$ at depths $\mathbf{1 0 - 1 5} \mathrm{m}$ causing massive mortality of benthic macrofauna, and in particular the extinction of shellfish Pecten jacobeus. The hypoxia persisted until the subsequent January when freshwater inflow increased, forcing the arrival of colder marine water near the bottom via the compensating flow.

Tilting of the halocline in response to wind stress. Contrary to coastal seas, where wind induced currents efficiently mix waters through the thermocline, in Krka estuary even the Bora wind is unable to destroy the halocline. When the water column is depleted of oxygen near the bottom, the induced vertical gyre will replace the water near the bottom with water that resided closer to the halocline, i.e., with water richer in oxygen. Hence, wind induced vertical circulation below the halocline will be beneficial to benthic organisms affected by hypoxia. However, sudden tilting of the halocline which may persist for a day results in massive mortality of marine shellfish organisms (and cultures) that reside near the halocline on the side of the lake that is opposite to wind blowing. 

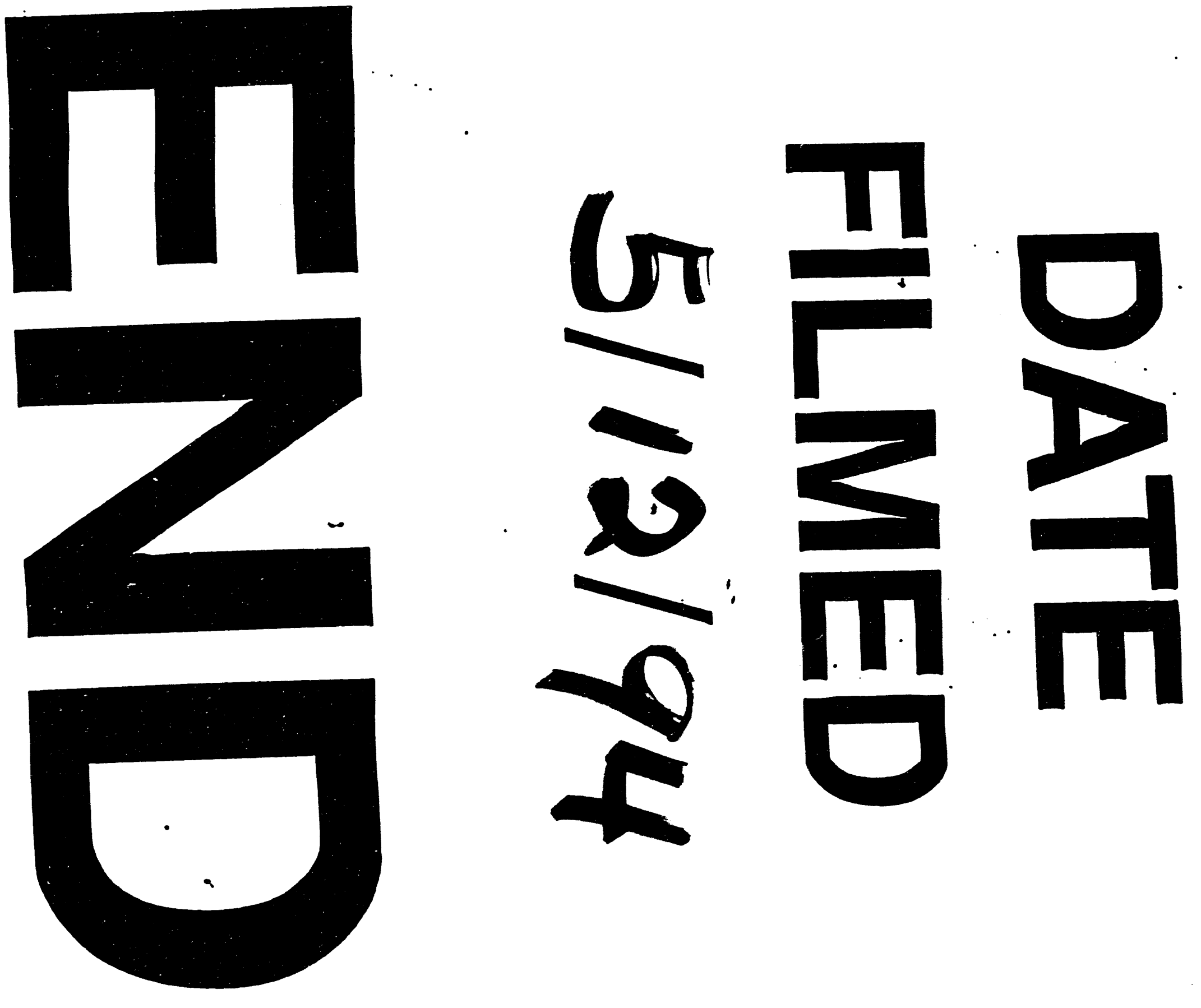